\title{
Metal-Catalyzed Synthesis and Transformations of $\beta$-Haloenol Esters
}

\author{
Victorio Cadierno \\ Laboratorio de Compuestos Organometálicos y Catálisis (Unidad Asociada al CSIC), Departamento de Química \\ Orgánica e Inorgánica, Facultad de Química, Universidad de Oviedo, Julián Clavería 8, E-33006 Oviedo, Spain; \\ vcm@uniovi.es; Tel.: +34-985-103453
}

Received: 23 March 2020; Accepted: 3 April 2020; Published: 4 April 2020

check for updates

\begin{abstract}
In the last years there has been an increasing interest in the search for protocols to obtain $\beta$-haloenol esters in an efficient and selective manner as they are versatile building blocks in synthetic organic chemistry. In this article, metal-catalyzed transformations allowing the access to both acyclic and cyclic (i.e., haloenol lactones) $\beta$-haloenol esters are reviewed. Metal-catalyzed reactions in which these molecules participate as substrates are also discussed.
\end{abstract}

Keywords: haloenol esters; haloenol lactones; enol esters; enol lactones; haloalkenes; haloalkynes; $\mathrm{C}-\mathrm{C}$ coupling reactions

\section{Introduction}

Alkenyl halides (haloalkenes) are a pivotal class of compounds in organic synthesis that can be used in a variety of carbon-carbon and carbon-heteroatom bond-forming reactions. For example, alkenyl halides are widely used as substrates in transition metal-catalyzed cross-coupling reactions $[1,2]$ and can be easily converted, through a metal-halogen exchange, into nucleophiles for 1,2-additions to carbonyl compounds [3]. Enol esters are also relevant olefinic derivatives with multitude of applications in modern organic chemistry [4-6]. The introduction of a halogen atom on the $C=C$ bond of the latter leads to functionalized molecules, i.e., $\alpha$-and $\beta$-haloenol esters (Figure 1), in which the reactivities of the haloalkene and enol ester functionalities can be combined and potentially exploited in numerous synthetic ways.<smiles>[R][R]([H])=C([X])OC([R])=O</smiles><smiles></smiles>

$\alpha$-haloenol esters

$\beta$-haloenol esters

$$
\mathrm{X}=\mathrm{F}, \mathrm{Cl}, \mathrm{Br}, \mathrm{I}
$$

Figure 1. Generic structures of $\alpha$ - and $\beta$-haloenol esters.

In this context, while the utility of $\alpha$-haloenol esters remains almost unexplored due to the lack of efficient and general synthetic methods [7-10], more accessible $\beta$-haloenol esters have gained significance in recent years as coupling partners in diverse chemical transformations. Several methodologies can be employed for the preparation $\beta$-haloenol esters, the most classical ones involving the acylation of haloenolate anions [11-15] or the haloacyloxylation of alkynes employing the elemental halogens [16-20], bis(pyridine)iodonium tetrafluoroborate ( $\left.\mathrm{IPy}_{2} \mathrm{BF}_{4}\right)$ [21-25], 
$N$-halosuccinimides (NXS; $\mathrm{X}=\mathrm{Cl}, \mathrm{Br}, \mathrm{I})$ [26-28], $\mathrm{PhI}(\mathrm{OAc})_{2}$ [29-31], trihaloisocyanuric acids [32] or $N, N$-dibromo- $p$-toluenesulfonamide $\left(\mathrm{TsNBr}_{2}\right)[33]$ as the electrophilic halogen source (Scheme 1$)$.

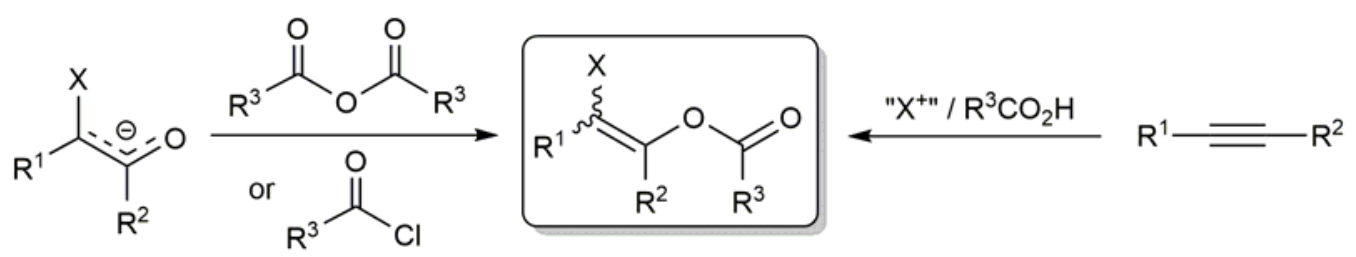

Scheme 1. Synthetic routes commonly employed in the preparation of $\beta$-haloenol esters.

Haloenol lactones of type A and $\mathbf{B}$ (see Figure 2) are also a relevant class of compounds due to their biological activity as enzymes inhibitors [34-38], and also because they are a common structural motif in many natural products [39].

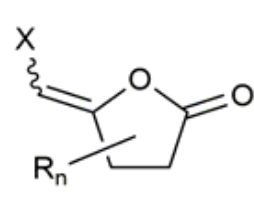

A $\quad x=B r, 1$<smiles>[X]C=C1OC(=O)CCC1([R])C</smiles>

B

Figure 2. Generic structures of haloenol lactones featuring biological activity.

Access to these molecules is usually achieved by halolactonization of the corresponding alkynoic acid using $\mathrm{I}_{2}$, NBS, NIS or related halogenating agents, reactions that deliver the haloenol lactone products as the $E$ isomers exclusively (Scheme 2) [34-38,40,41]. We would like also to highlight here that asymmetric versions of these halolactonization processes have been recently described employing cinchona alkaloid-based organocatalysts [42-44]. A couple of illustrative examples are given in Scheme 3. Mechanistic investigations indicated a bifunctional behavior of the organocatalysts, activating simultaneously the halogenating agent and the carboxylic acid unit.

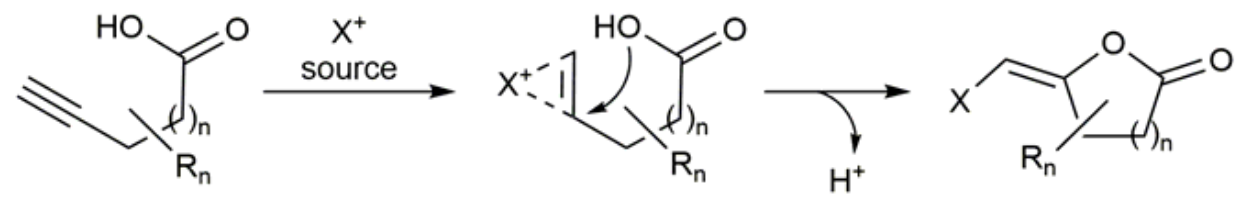

Scheme 2. The E-halolactonization of alkynoic acids.

Synthetic approaches to both acyclic and cyclic $\beta$-haloenol esters have been expanded in the most recent years by the aid of metal catalysts, employing in most of the cases in situ generated or preformed haloalkynes [45-47] as starting materials, and are the subject of the present review article. Thus, the catalytic synthesis of $\beta$-haloenol esters will be discussed, as well as the participation of these molecules in metal-catalyzed cross-coupling processes. 
<smiles>C#CCC(CC#C)(C(=O)O)C(=O)OC</smiles>

(79\% yield; $86 \%$ ee)<smiles>C#CC[C@]1(C(=O)OC)C/C(=C\Br)OC1=O</smiles><smiles>C#CCC(CC#C)(C(=O)O)C(=O)O</smiles>

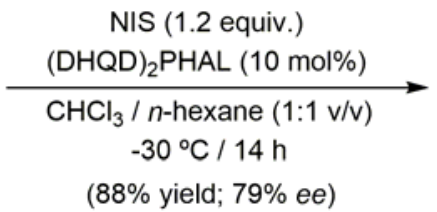<smiles>C#CC[C@]1(c2ccccc2)C/C(=C\I)OC1=O</smiles>

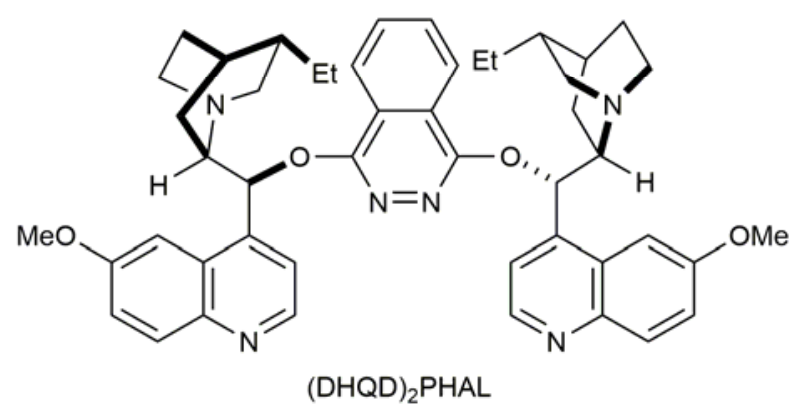

Scheme 3. Enantioselective halolactonization of alkynoic acids employing an organocatalyst.

\section{Metal-Catalyzed Synthesis of $\beta$-Haloenol Esters}

The first metal-mediated route to access $\beta$-haloenol esters was described by Ichikawa and co-workers in 1974 (Scheme 4) [48]. They found that 1-propynylbenzene readily undergoes a trans-acetoxythallation, upon treatment of with $\mathrm{Tl}(\mathrm{OAc})_{3}$ in acetic acid, to give a separable mixture of the two isomeric vinylthallium(III) compounds $\mathbf{1}$ and $\mathbf{2}$. Subsequent reaction of the major isomer $\mathbf{1}$ with the corresponding copper(I) or copper(II) halide salt in acetonitrile resulted in the formation of the $(E)-\beta$-haloenol acetates $3-5$, which were isolated in low yield (11-58\%). The halogenodethallation step proceeded in all the cases with complete retention of the $\mathrm{C}=\mathrm{C}$ configuration.

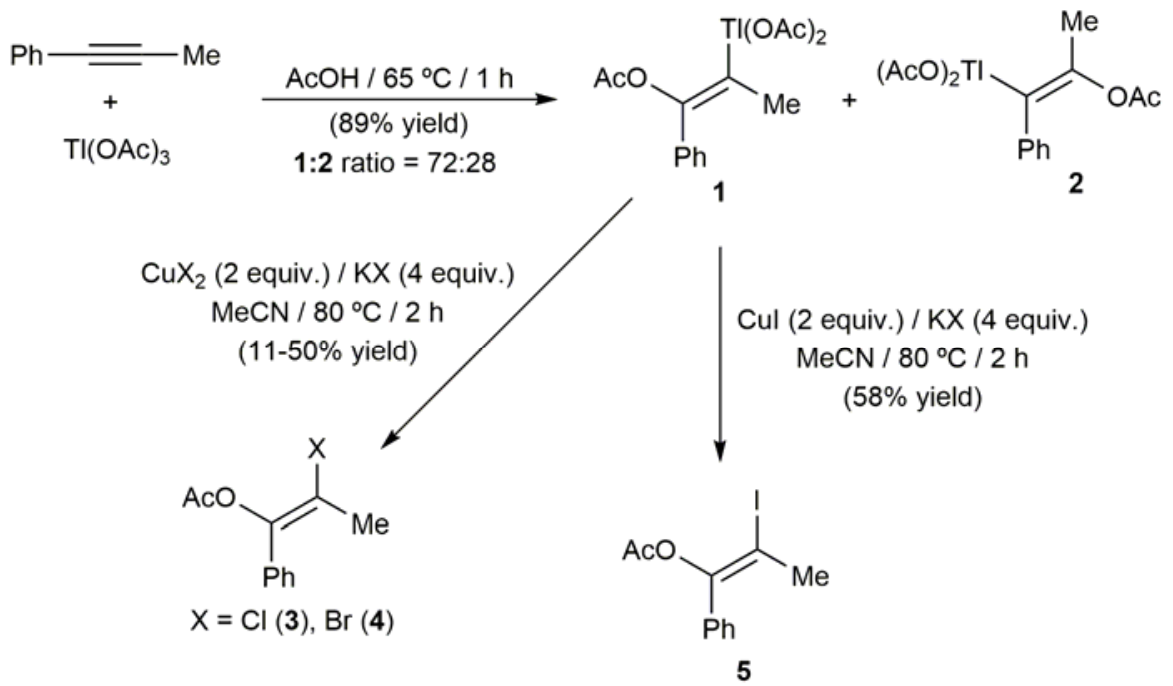

Scheme 4. Thallium-mediated synthesis of the (E)- $\beta$-haloenol acetates 3-5 from 1-propynylbenzene. 
After this seminal work, more general methodologies based on the use of $\mathrm{Hg}$, $\mathrm{Ag}$, $\mathrm{Au}$ and $\mathrm{Pd}$ metals have been described.

\subsection{Hg-Catalyzed Synthesis of $\beta$-Haloenol Esters}

Extending previous studies with non-halogenated molecules [49], Krafft and Katzenellenbogen described in 1981 a synthetic route to haloenol lactones through the mercury-catalyzed cyclization of halogen-substituted alkynoic acids [50]. In particular, they were able to generate compounds 8 and 9 in moderate yield (40-69\%) by treatment of dichloromethane solutions of 5-chloro-4-pentynoic acid (6) and 5-bromo-4-pentynoic acid (7), respectively, with $10 \mathrm{~mol} \%$ of $\mathrm{Hg}(\mathrm{OAc})_{2}$ or $\mathrm{Hg}\left(\mathrm{OCOCF}_{3}\right)_{2}$ (Scheme 5). The reactions proceed through the anti addition of the carboxylate group to the $\mathrm{C} \equiv \mathrm{C}$ bond activated by $\pi$-coordination to mercury and, contrary to the halolactonization methods commented above (see Scheme 2), they delivered the haloenol lactone products as the $Z$ isomers exclusively.

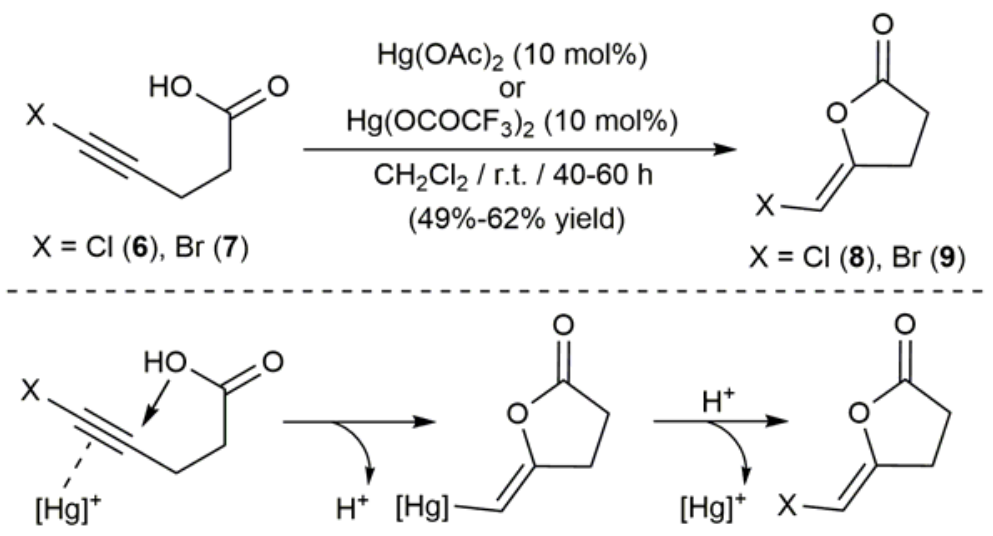

Scheme 5. Mercury-catalyzed cyclization of the alkynoic acids 6 and 7.

In an independent study, Krantz and co-workers extended this cyclization reaction to 5-iodo-4-pentynoic acid (10). However, the use of an excess of mercury(II) trifluoroacetate was in this case needed, and the (Z)-iodoenol lactone $\mathbf{1 1}$ could only be obtained in low yield (Scheme 6) [51].

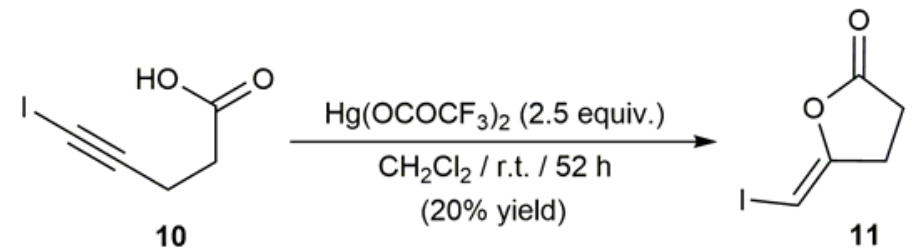

Scheme 6. Mercury-mediated cyclization of 5-iodo-4-pentynoic acid.

Barluenga and co-workers achieved also the stereoselective synthesis of the acyclic (Z)- $\beta$-iodoenol acetates 12 through a difunctionalization reaction of the corresponding internal alkynes by means of the $\mathrm{Hg}(\mathrm{OAc})_{2} / \mathrm{I}_{2}$ combination (Scheme 7) [52]. The formation of a cationic intermediate of type $\mathrm{C}$, which undergoes the attack of the acetate anion, was proposed by the authors as the most likely reaction pathway. 


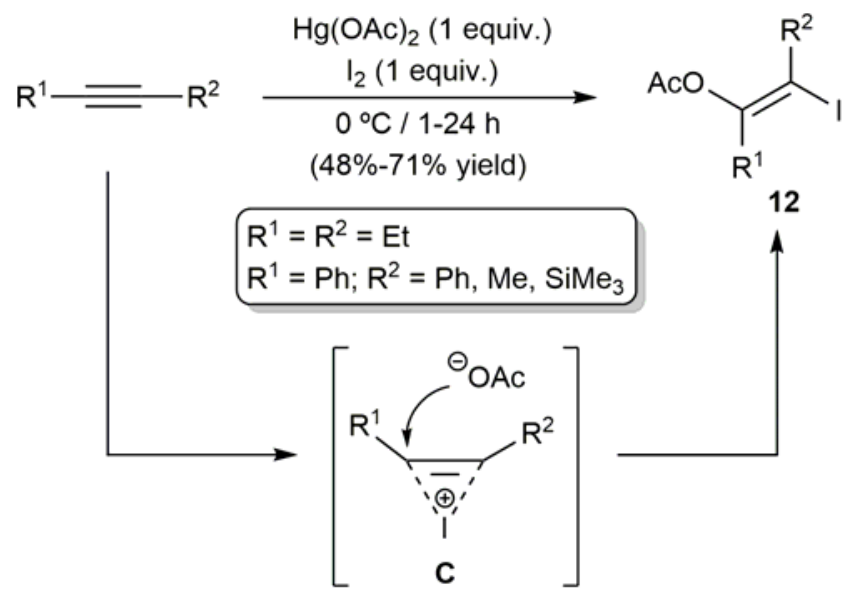

Scheme 7. Synthesis of acyclic (E)- $\beta$-iodoenol acetates by bifunctionalization of internal alkynes.

\subsection{Ag-Catalyzed Synthesis of $\beta$-Haloenol Esters}

In 1991, the group of Katzenellenbogen described a two-steps protocol for the selective Z-bromoenol lactonization of akynoic acids employing stoichiometric amounts of $\mathrm{AgNO}_{3}$ and $\mathrm{Br}_{2}$ (Scheme 8) [53]. The process involves the initial silver-mediated cyclization of the substrates to generate the metallated lactones $\mathbf{D}$, which subsequently undergo an $\mathrm{Ag} / \mathrm{Br}$ exchange upon treatment with $\mathrm{Br}_{2}$. Both 5 - and 6-membered ring lactones could be synthesized employing this methodology, whose efficiency was found to be conditioned by the substitution pattern of the starting alkynoic acids. In particular, the presence of substituents in $\alpha$ and $\beta$ position with respect to the carboxylate group $\left(\mathrm{R}^{1}\right.$ and $\left.\mathrm{R}^{2}\right)$ was key to obtain the products in high yields, those substrates unsubstituted in these positions leading to very poor results ( $2-5 \%$ yield). Additionally, of note is the fact that the lactonization process resulted ineffective with akynoic acids featuring an internal $\mathrm{C} \equiv \mathrm{C}$ bond or when $\mathrm{I}_{2}$ was employed as the electrophile.

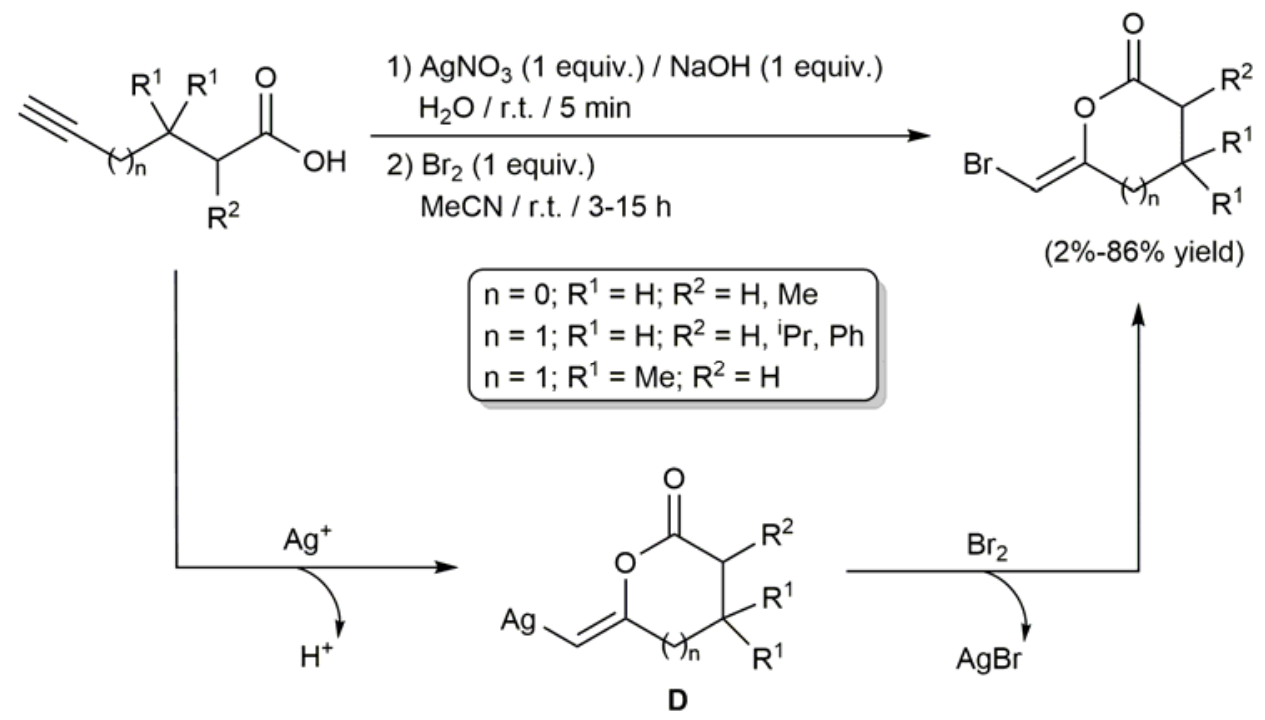

Scheme 8. Silver-mediated Z-bromoenol lactonization of alkynoic acids.

The first general and truly catalytic protocol to obtain acyclic $\beta$-haloenol esters came to light only in 2010 and it was developed by Jiang's group [54]. As shown in Scheme 9, they were able to synthesize a large variety of $(Z)$-haloenol acetates 13 through an $\mathrm{AgBF}_{4}$-catalyzed difunctionalization reaction of terminal alkynes with $N$-halosuccinimides (NXS) and acetic anhydride. In the reactions, which were performed at $120{ }^{\circ} \mathrm{C}$ with $5 \mathrm{~mol} \%$ of $\mathrm{AgBF}_{4}$ and employing directly $\mathrm{Ac}_{2} \mathrm{O}$ as the 
solvent, the silver(I) cation plays a dual role. Thus, it first acts a $\sigma$-activator allowing the in situ generation of the corresponding haloalkynes $\mathrm{RC} \equiv \mathrm{CX}$, and subsequently as a $\pi$-activator facilitating the nucleophilic attack of the acetate anion to the $\mathrm{C} \equiv \mathrm{C}$ bond. The process featured an exquisite regio- and stereoselectivity, and tolerated the presence of common functional groups in the alkyne substrates.

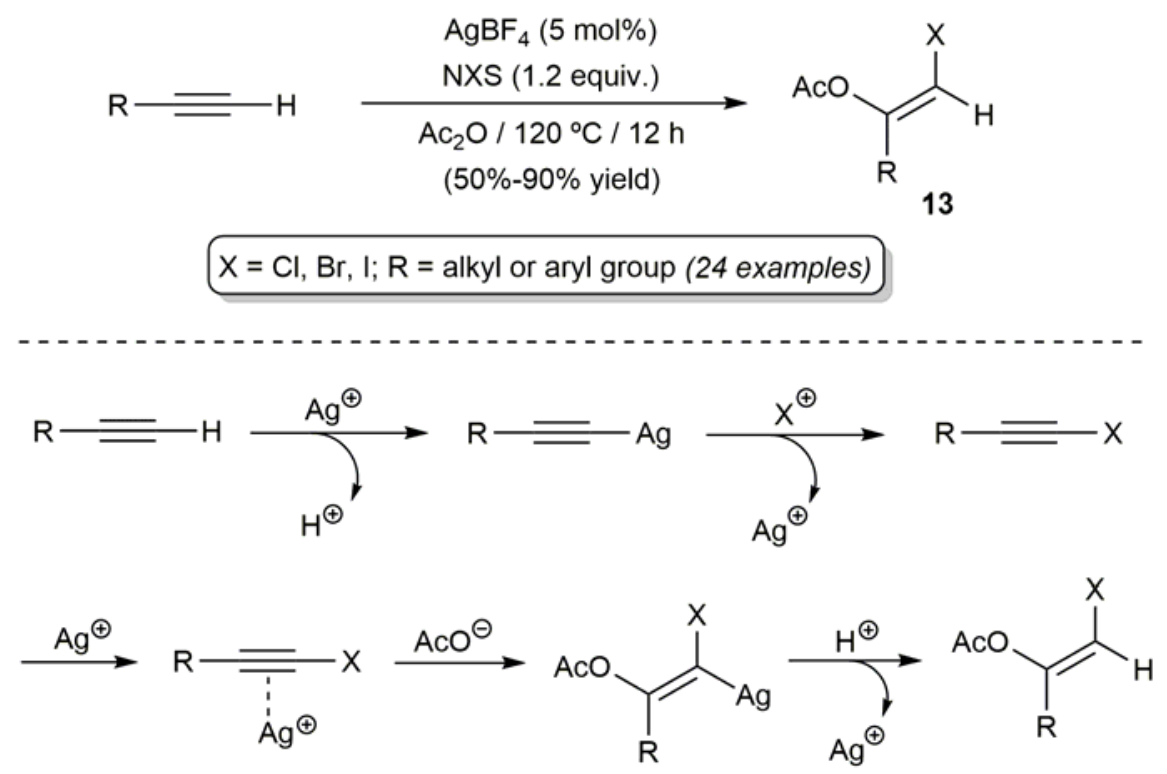

Scheme 9. Silver-catalyzed synthesis of (Z)- $\beta$-haloenol acetates from terminal alkynes.

\subsection{Au-Catalyzed Synthesis of $\beta$-Haloenol Esters}

In 2006, and almost simultaneously, the groups of Michelet and Pale demonstrated that both terminal and internal alkynoic acids could be efficiently cyclized under mild conditions employing $\mathrm{AuCl}$ as a catalyst [55,56]. 5-Bromo-4-pentynoic acid (7) and 6-bromo-5-hexynoic acid (14) made part of the substrates studied by Pale and, from them, the Z-bromoenol lactones 9 and 15, respectively, could be synthesized in excellent yield (Scheme 10) $[56,57]$. The cycloisomerization reactions, which were performed at room temperature with $10 \mathrm{~mol} \%$ of $\mathrm{AuCl}$ in combination with $\mathrm{K}_{2} \mathrm{CO}_{3}(10 \mathrm{~mol} \%$ ), involve the intramolecular exo-dig anti-addition of the carboxylate anion generated by deprotonation with the $\mathrm{K}_{2} \mathrm{CO}_{3}$ base to the $\mathrm{C} \equiv \mathrm{C}$ bond, which is activated by $\pi$-coordination to the $\mathrm{Au}^{+}$cation. Final protonolysis of the gold-carbon bond in the metallated intermediate $\mathbf{E}$ liberates the enol-lactone products.

More recently, Nolan and coworkers reported the regio- and stereoselective cyclization of 6-bromo-5-hexynoic acid (14) and 7-bromo-6-heptynoic acid (16) into lactones 15 and 17 employing catalytic amounts of the hydroxo-bridged dinuclear gold(I) complex $\left[\{\mathrm{Au}(\mathrm{IPr})\}_{2}(\mu-\mathrm{OH})\right]\left[\mathrm{BF}_{4}\right](\mathbf{1 8}$; $\mathrm{IPr}=N, N^{\prime}$-bis(2,6-di-iso-propylphenyl)imidazole-2-ylidene) (Scheme 11) [58]. The addition of an external base was in this case not needed, the bridging $\mathrm{OH}$ ligand facilitating the generation of the carboxylate anion. It is also worthy of note that, while the conversion of $\mathbf{1 4}$ into $\mathbf{1 5}$ proceeded rapidly at r.t. with only $0.1 \mathrm{~mol} \%$ of $\mathbf{1 8}$, the generation of the $\varepsilon$-alkylidene-lactone $\mathbf{1 7}$ from 16 resulted in being more demanding and an increase of the Au loading, temperature and reaction time was required. 

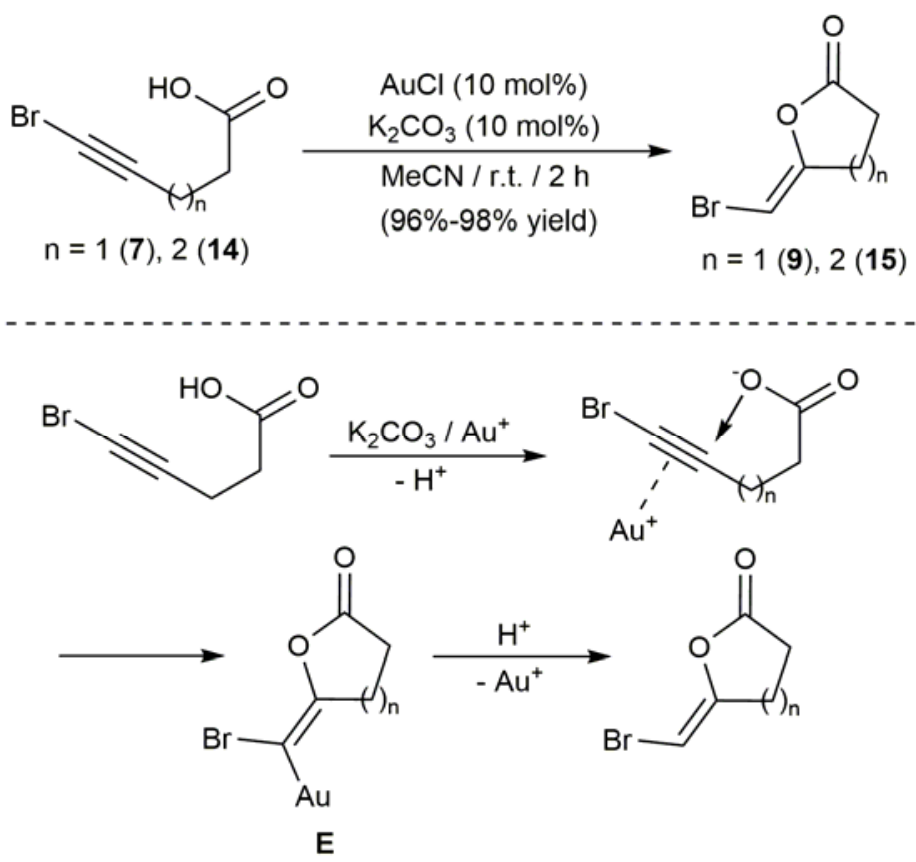

Scheme 10. AuCl-catalyzed cycloisomerization of bromo-substituted alkynoic acids.

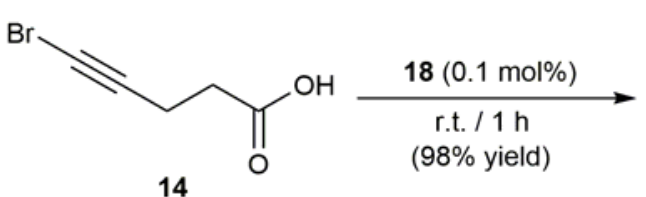

14<smiles>O=C(O)CCCC#CBr</smiles>

16<smiles>O=C1CCC/C(=C/Br)O1</smiles>

15<smiles>O=C1CCCC/C(=C/Br)O1</smiles>

17<smiles>CC#CC1N(c2c(C(C)C)cccc2C(C)C)C=CN1c1c(C(C)C)cccc1C(C)OCC1N(c2c(CCC)cccc2C(C)C)C=CN1c1c(C(C)C)cccc1C(C)C</smiles>

Scheme 11. Cycloisomerization of alkynoic acids 14 and $\mathbf{1 6}$ catalyzed by $\left[\{\mathrm{Au}(\mathrm{IPr})\}_{2}(\mu-\mathrm{OH})\right]\left[\mathrm{BF}_{4}\right](\mathbf{1 8})$.

Making use of a catalytic system composed of the gold(I) complex $\left[\mathrm{AuCl}\left(\mathrm{PPh}_{3}\right)\right]$ and the chloride abstractor $\mathrm{AgPF}_{6}$, a broad scope procedure for the preparation of acyclic (Z)- $\beta$-iodoenol esters was also recently developed by Cadierno and co-workers (Scheme 12) [59-61]. The process, which proceeds under mild conditions and tolerates the presence of several functional groups in the substrates, involves the intermolecular addition of carboxylic acids to iodoalkynes, the latter being activated towards the carboxylate anion attack by $\pi$-coordination to the in situ generated gold(I) cation $\left[\mathrm{Au}\left(\mathrm{PPh}_{3}\right)\right]^{+}$. As expected, the carboxylate anion adds selectively to the more electrophilic C-2 carbon of the 
iodoalkyne [45-47] and, as usually observed in the chemistry of $\pi$-alkyne-gold complexes [62], the addition takes places in an anti fashion, thus affording the olefinic products 19 in a complete regioand stereoselective manner. With a couple of representative examples, i.e., the addition of acetic acid to 1-(chloroethynyl)-4-methylbenzene and 1-bromooct-1-yne, the authors also demonstrated the applicability of this procedure for the synthesis of related $(Z)-\beta$-chloroenol and $(Z)-\beta$-bromoenol esters [60].

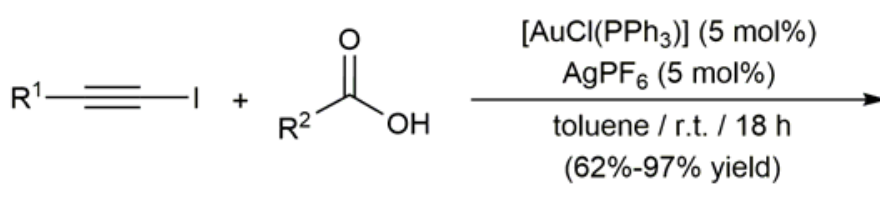

$$
\begin{aligned}
& R^{1}=\text { alkyl or aryl group } \\
& R^{2}=\text { alkyl, aryl, heteroaryl or alkenyl group (50 examples) }
\end{aligned}
$$

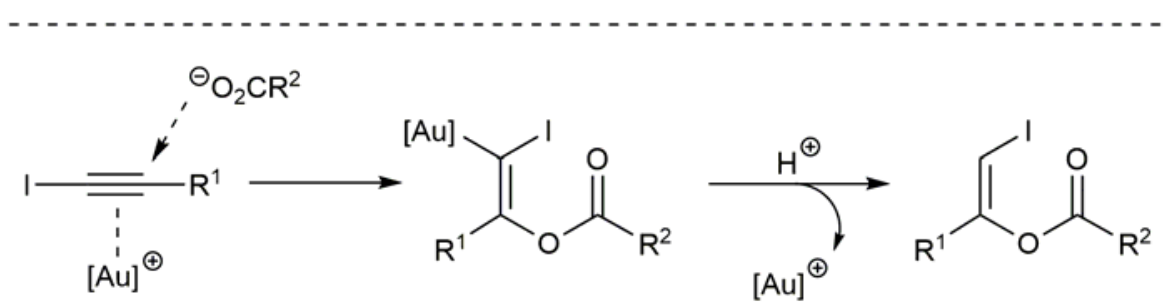

Scheme 12. Gold-catalyzed intermolecular addition of carboxylic acids to iodoalkynes.

Following the same gold-catalyzed protocol, Muthusamy and Pansare synthesized later a large family of (Z)- $\beta$-iodoenol cinnamates $\mathbf{2 0}$ starting from the corresponding aromatic or aliphatic iodoalkyne and cinnamic acid (Figure 3) [63].<smiles>[R]/C(=C/I)OC(=O)/C=C/[Al]</smiles>

20

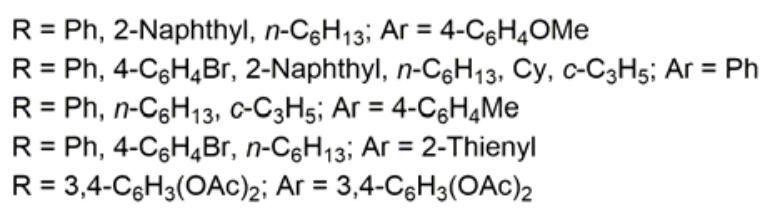

Figure 3. Structure of the (Z)- $\beta$-iodoenol cinnamates 20.

On the other hand, Zhang and coworkers reported the efficient synthesis of different $\beta$-haloenol esters of type 22 by rearrangement of the corresponding halo-substituted propargylic carboxylates 21 (Scheme 13) [64]. The process, which is catalyzed by the gold(I) complex [Au( $\left.\left.\mathrm{NTf}_{2}\right)\left(\mathrm{PPh}_{3}\right)\right]$ $\left(\mathrm{NTf}_{2}=\right.$ bis(trifluoromethane)sulfonamide) under mild conditions (r.t.), involves the initial activation of the $\mathrm{C} \equiv \mathrm{C}$ bond of the substrates by the cationic gold species $\left[\mathrm{Au}\left(\mathrm{PPh}_{3}\right)\right]^{+}$(intermediate $\mathbf{F}$ ), followed by 1,2-migration of the carboxylate group via the cyclic intermediate $\mathbf{G}[64,65]$. The allyl cation $\mathbf{H}$ thus generated evolves into the final products 22 by deprotonation and protodeauration. It is important to note that the use of rigorously anhydrous conditions is mandatory for the rearrangement process to proceed selectively since, in the presence of water, hydrolysis of intermediate $\mathrm{G}$ readily takes place leading to the corresponding $\alpha$-halomethyl ketones 23 [64,66,67]. In line with this, we would like to mention that efficient protocols for the hydration of haloalkynes $\mathrm{RC} \equiv \mathrm{CX}$ into $\alpha$-halomethyl ketones $\mathrm{RC}(=\mathrm{O}) \mathrm{CH}_{2} \mathrm{X}$ employing catalytic systems composed of $\mathrm{AgF} / \mathrm{CF}_{3} \mathrm{CO}_{2} \mathrm{H}$ [68], $\mathrm{In}(\mathrm{OTf})_{3} / \mathrm{CH}_{3} \mathrm{CO}_{2} \mathrm{H}$ [69] and $\mathrm{Cu}(\mathrm{OAc})_{2} \cdot \mathrm{H}_{2} \mathrm{O} / \mathrm{CF}_{3} \mathrm{CO}_{2} \mathrm{H}$ [70] have been described, in which hydrolysis of a $\beta$-haloenol acetate or trifluoroacetate intermediate $\left(\mathrm{RC}\left(\mathrm{O}_{2} \mathrm{CR}^{\prime}\right)=\mathrm{CHX} ; \mathrm{R}^{\prime}=\mathrm{CH}_{3}\right.$ or $\left.\mathrm{CF}_{3}\right)$ has been proposed as the most likely reaction pathway. 


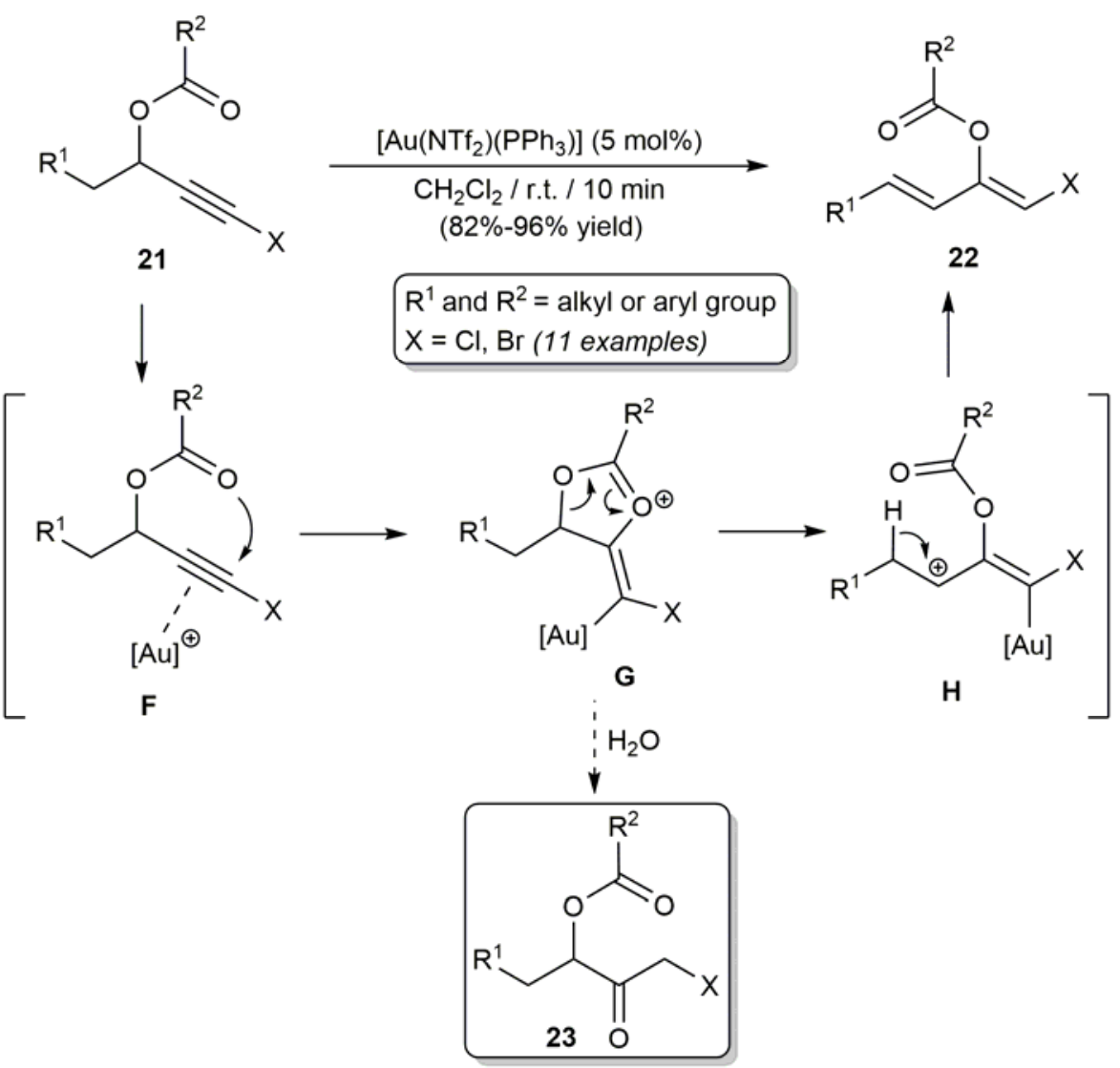

Scheme 13. Gold(I)-catalyzed rearrangement of halo-substituted propargylic carboxylates.

\subsection{Pd-Catalyzed Synthesis of $\beta$-Haloenol Esters}

In 2011, an efficient approach to (Z)- $\beta$-haloenol acetates 24 was developed by Zhu and coworkers by coupling haloalkynes with allyl acetate, employing a catalytic system composed of $\mathrm{Pd}(\mathrm{OAc})_{2}$ and the bidentate ligand 4,4'-dimethoxy-2,2'-bipyridine (Scheme 14) [71]. The regio- and stereoselectivity of the process was exquisite, the formation of byproducts being in no case observed. A reaction pathway involving the initial acetoxypalladation of the alkyne, followed by insertion of the allyl acetate molecule into the Pd-C bond of the resulting alkenyl-palladium intermediate $\mathbf{I}$, was proposed by the authors. A final $\beta$-elimination step in the alkyl-palladium species $\mathbf{J}$ furnished the (Z)- $\beta$-haloenol acetate products 24. Both chloro- and bromoalkynes participated in the reaction, but the process resulted inoperative with iodoalkynes due to their decomposition under the reaction conditions employed. Negative results were also obtained when substituted allyl acetates, such as 1-phenylallyl acetate, 2-methylallyl acetate or cinnamyl acetate, were used as the olefinic coupling partners.

On the other hand, in the context of their studies on the cycloisomerization of alkynoic acids with indenediide-based palladium pincer catalysts, the group of Martin-Vaca and Bourissou also reported the efficient and selective conversion of 6-bromo-5-hexynoic acid (14) into the corresponding lactone 15 (see Scheme 11) employing complexes 25 and 26 (5 mol \% of Pd at $90{ }^{\circ} \mathrm{C}$; see Figure 4) [72,73]. Analogously to the case of hydroxo-gold complex $\left[\{\mathrm{Au}(\mathrm{IPr})\}_{2}(\mu-\mathrm{OH})\right]\left[\mathrm{BF}_{4}\right](\mathbf{1 8})$, a reaction mechanism involving the intramolecular exo-dig anti-addition of the carboxylate anion on the $\pi$-activated $C \equiv C$ bond of substrate was proposed, with the electron-rich indenediide ligand being in this case responsible for the deprotonation of the carboxylic acid unit. 

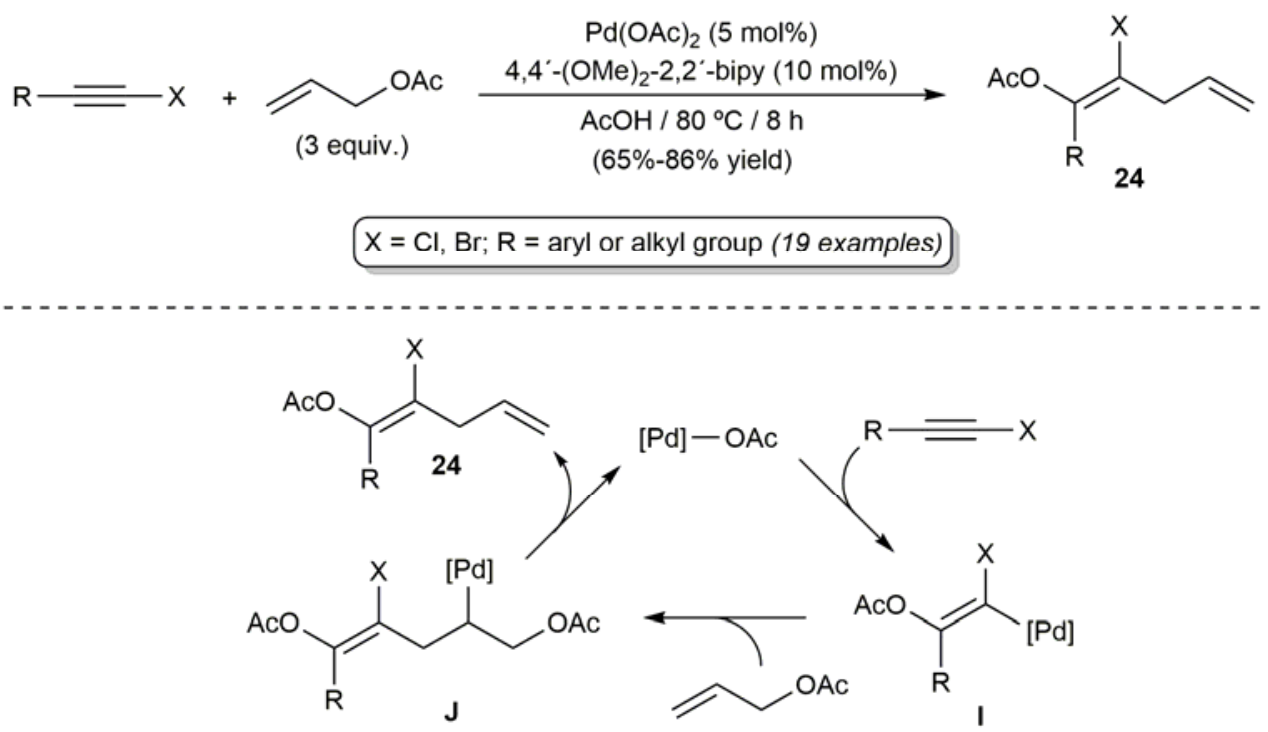

Scheme 14. Palladium-catalyzed coupling of haloalkynes with allyl acetate.
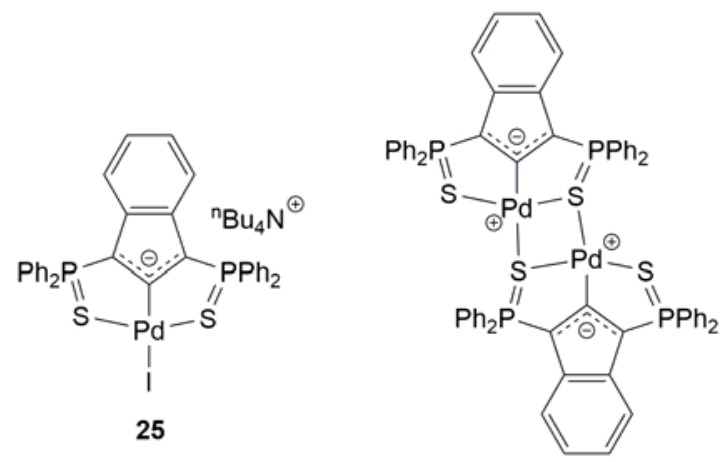

26

Figure 4. Structure of the palladium(II) pincer complexes 25 and $\mathbf{2 6 .}$

\section{Metal-Catalyzed Transformations of $\beta$-Haloenol Esters}

As commented in the introduction of this article, haloalkenes are widely employed in synthetic organic chemistry for the construction of polysubstituted olefins through transition-metal catalyzed cross-coupling reactions $[1,2]$. In this section, the participation of $\beta$-haloenol esters in metal-catalyzed transformations is discussed.

\subsection{Acyclic $\beta$-Haloenol Esters}

In the context of their studies on the palladium-catalyzed coupling of haloalkenes with organoboron compounds, Suzuki and Miyaura reported in 1992 the first cross-coupling reactions involving a $\beta$-haloenol ester [74]. Thus, as shown in Scheme 15, the treatment of the bromoenol acetate 27 with different alkyl-, aryl- and alkenyl-boron reagents in the presence of catalytic amounts of $\left[\mathrm{Pd}\left(\mathrm{PPh}_{3}\right)_{4}\right]$ and a base cleanly afforded the corresponding trisubstituted olefins, which were isolated in high yields (73-89\%) and with complete retention of the stereochemistry of the starting $\mathrm{C}=\mathrm{C}$ bond. 


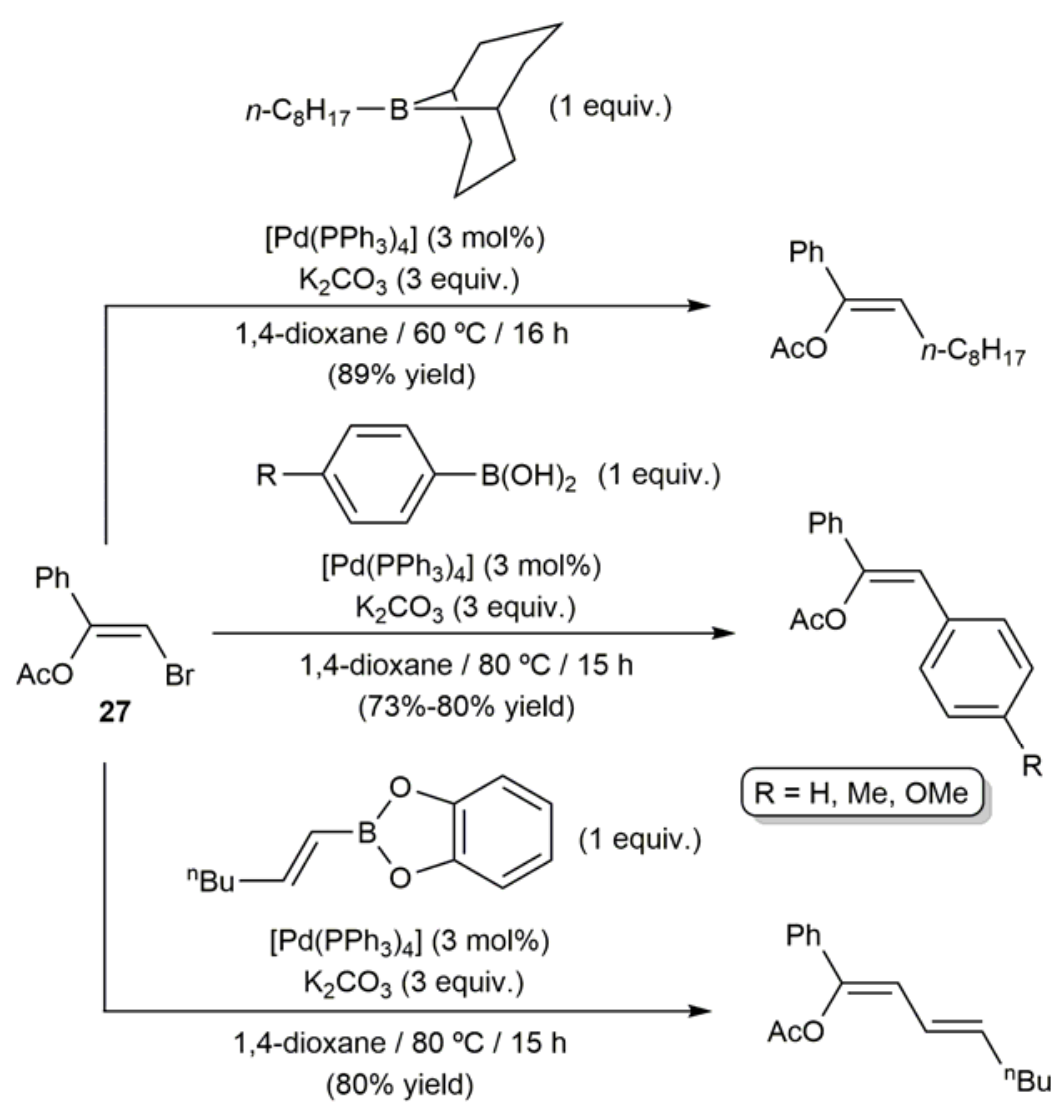

Scheme 15. Pd-catalyzed coupling of (Z)- $\beta$-bromoenol acetate 27 with organoboron compounds.

After this seminal contribution, several works reporting the use of $\beta$-haloenol esters as substrates in Suzuki-Miyaura type reactions have appeared in the literature. For example, Zhang and coworkers described the preparation of the aryldiene 29 through the cross-coupling of 28 with phenylboronic acid catalyzed by the $\left[\mathrm{Pd}_{2}(\mathrm{dba})_{3}\right] / S P h o s$ system (dba = dibenzylideneacetone; see Scheme 16) [64].

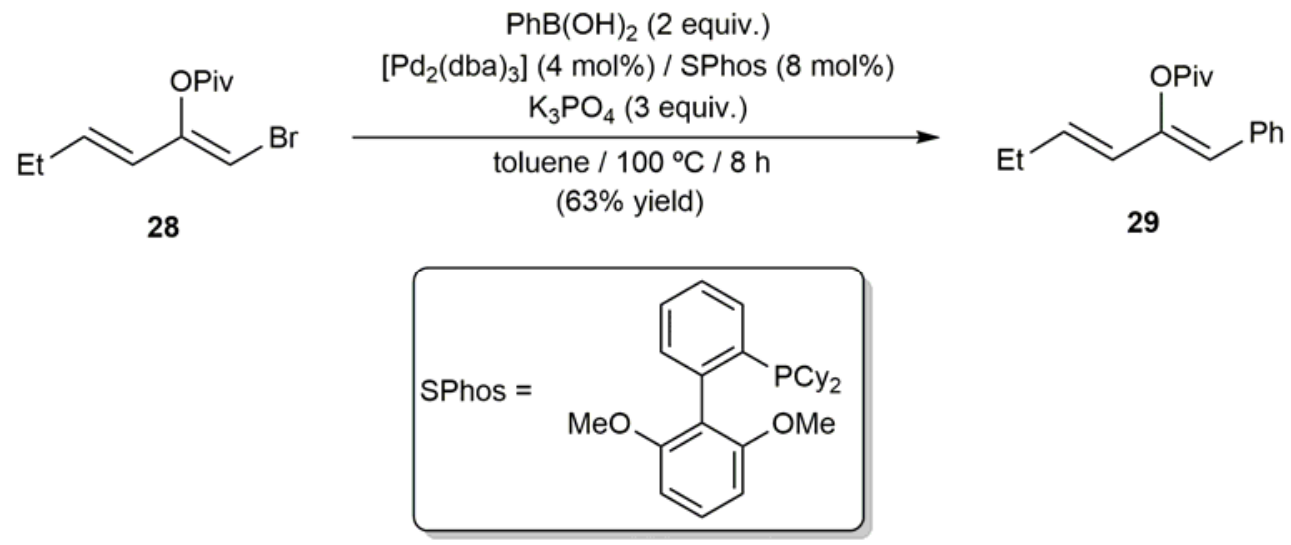

Scheme 16. Synthesis of the aryldiene 29 through Suzuki-Miyaura coupling of 28 with $\mathrm{PhB}(\mathrm{OH})_{2}$.

In a wider scope study, Cadierno, Pizzano and coworkers employed the $(Z)-\beta$-iodoenol acetates 30 as starting materials for the synthesis of several (Z)-1-substituted-2-arylvinyl acetates 31, via $\left[\mathrm{Pd}\left(\mathrm{PPh}_{3}\right)_{4}\right]$-catalyzed coupling of 30 with aromatic boronic acids (Scheme 17) [59,61]. Remarkably, the asymmetric hydrogenation of compounds $\mathbf{3 1}$ to afford the corresponding chiral homobenzylic esters 32 , of interest as precursors of synthetically useful chiral alcohols by deacylation, could be successfully 
accomplished by the same authors employing rhodium(I) catalysts containing optically pure bidentate phosphine-phosphite ligands (ee up to $98 \%$ ) $[59,61]$.
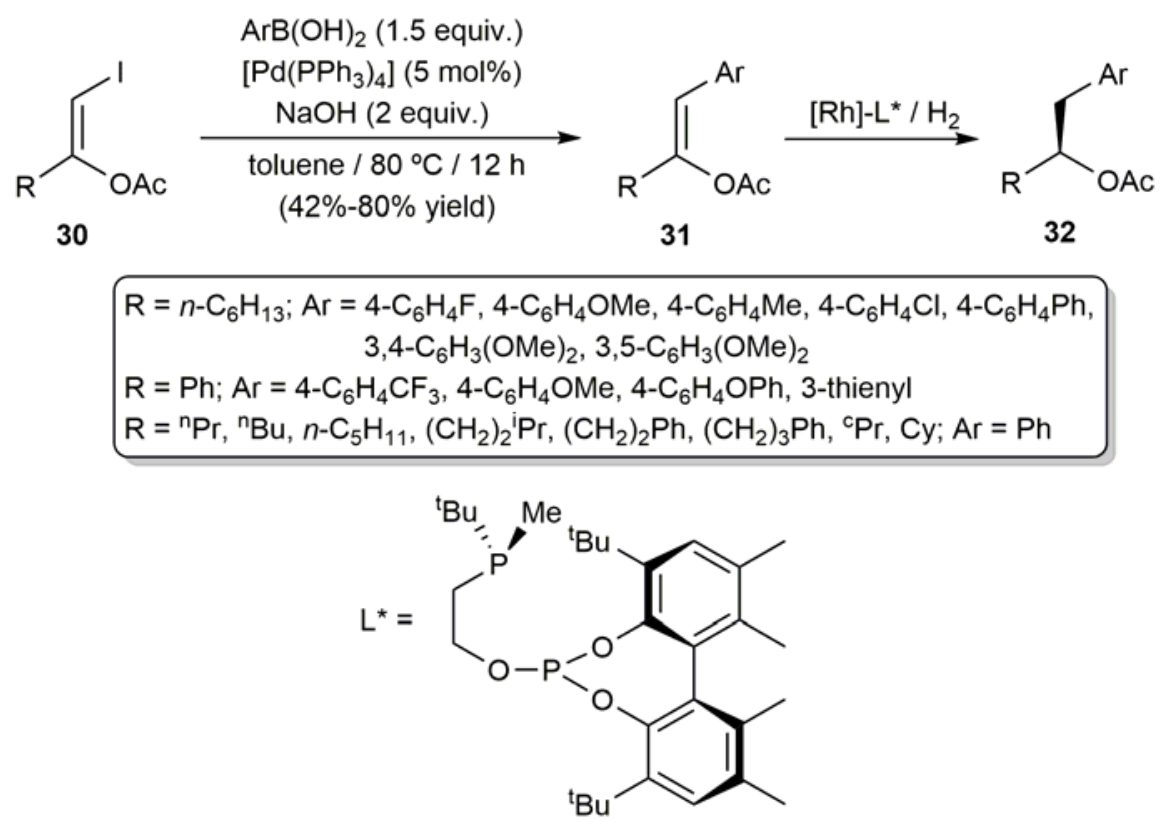

Scheme 17. (Z)- $\beta$-Iodoenol acetates as starting materials for the preparation of chiral homobenzylic esters.

As shown in Scheme 18, the Suzuki-Miyaura coupling of (Z)-2-bromovinyl esters 34, generated by stereocontrolled dehydrobromination of 1,2-dibromoethyl esters 33 with DBU (1,8-diazabicyclo[5.4.0]undec-7-ene) and a catalytic amount of hydroquinone, with stereodefined alkenylboronic acids provided also an efficient route for the selective construction of $(Z, E)$ - and $(Z, Z)$-conjugated dienyl esters (35 and 36, respectively), molecules of enormous interest since they can be employed as precursors for the preparation of several natural products through Diels-Alder reactions [75].

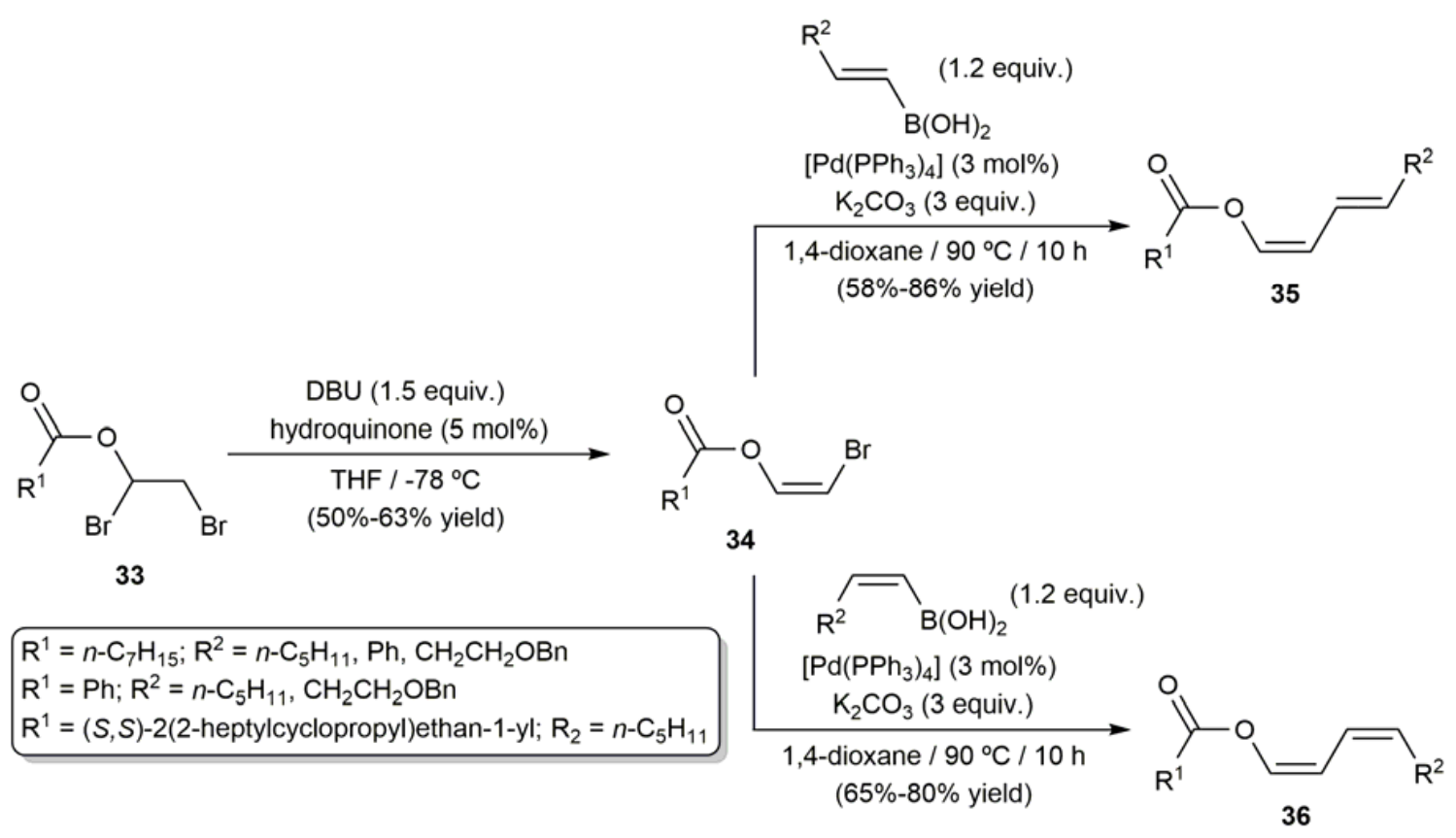

Scheme 18. Stereoselective synthesis of conjugated dienyl esters through Suzuki-Miyaura-type cross-coupling reactions. 
In addition, the tetrasubstituted olefins $\mathbf{3 7 - 4 0}$ (see Figure 5) were also synthesized in high yields (72-99\%) by Suzuki-Miyaura coupling of the corresponding $\beta$-haloenol acetates with boronic acids (the $\mathrm{C}-\mathrm{C}$ bond formed is highlighted in bold) $[28,31,71]$.<smiles>CC(=O)OC(=C(c1ccccc1)c1ccccc1)c1cc(C)cc(C)c1</smiles><smiles>COc1ccc(/C(OC(C)=O)=C(\F)[18F])cc1</smiles>

38<smiles>[R]C(=C(O[C])c1ccc(OC)cc1)c1ccccc1</smiles><smiles>C=CC/C(=C(\OC(C)=O)c1ccccc1)c1ccccc1</smiles>

40

$\mathrm{R}=\mathrm{Ph},(E)-\mathrm{CH}=\mathrm{CHPh}, \mathrm{C}(\mathrm{Ph})=\mathrm{CH}_{2}$

Figure 5. Structure of the tetrasubstituted olefins 37-40.

Probably, the reactions of $\beta$-haloenol esters most widely studied to date are the palladium-catalyzed Sonogashira-type couplings with terminal alkynes $[30,54,60,71,76-78]$. In this regard, a large number of (Z)- and (E)- $\beta$-haloenol esters (both chlorides, bromides and iodides) have been successfully coupled with alipahic and aromatic alkynes, 1,3-enynes or propargylic alcohols to generate the corresponding enynyl ester products in high yields and with complete preservation of the $\mathrm{C}=\mathrm{C}$ bond stereochemistry of the starting olefins (the results obtained in references $[60,76,77]$ are depicted in Scheme 19).
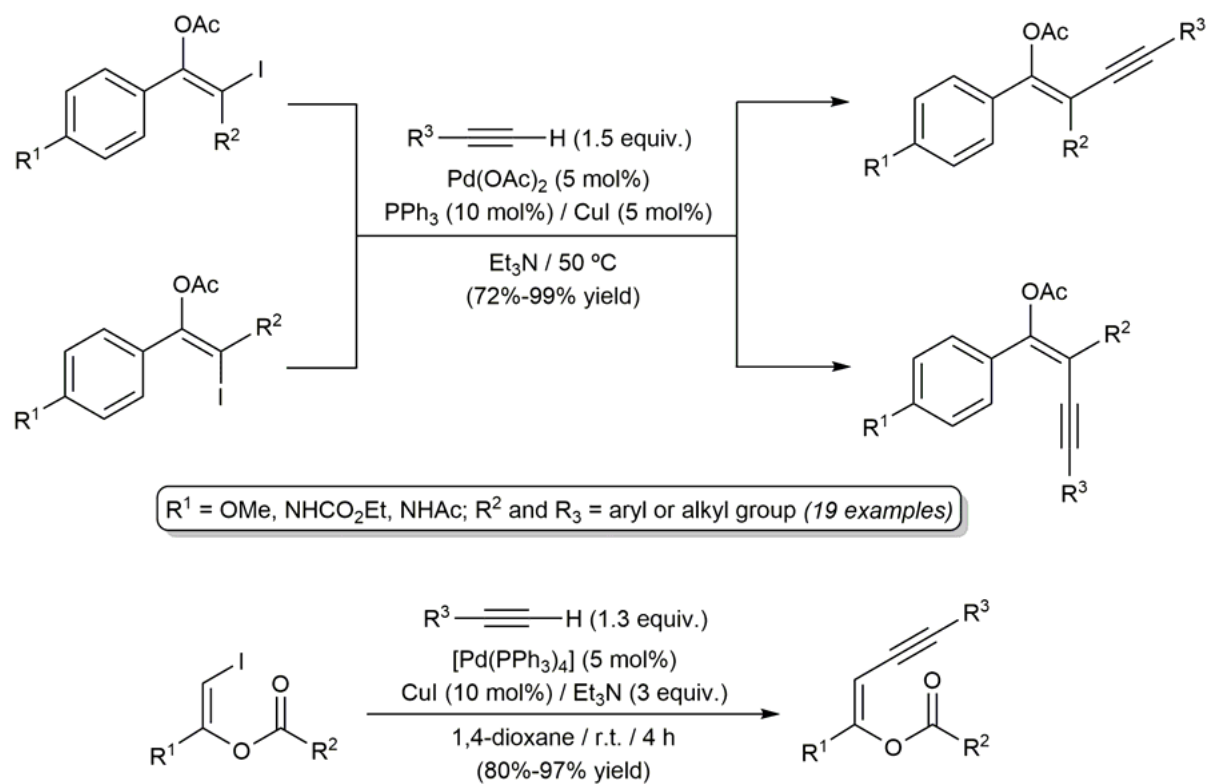

$$
\mathrm{R}^{1}=\text { alkyl or aryl group; } \mathrm{R}^{2} \text { and } \mathrm{R}^{3}=\text { alkyl, aryl or alkenyl group (29 examples) }
$$

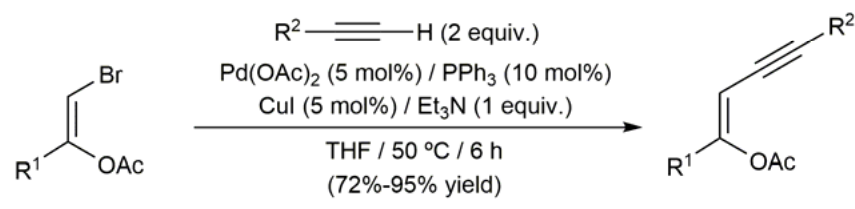

$\mathrm{R}^{1}=$ alkyl or aryl group; $\mathrm{R}^{2}=$ alkyl, aryl, alkenyl or ferrocenyl group (36 examples)

Scheme 19. Sonogashira-type coupling reactions of $\beta$-haloenol esters. 
The main interest in these Sonogashira-type reactions is that the enynyl ester products can be employed as starting materials for the generation of polysubstituted furans via metal-catalyzed [76,77] or halogen-induced electrophilic cyclization reactions [30,79-81]. Illustrative examples are shown in Scheme 20.<smiles>[R]C#CC=C([R])O[Na]</smiles>

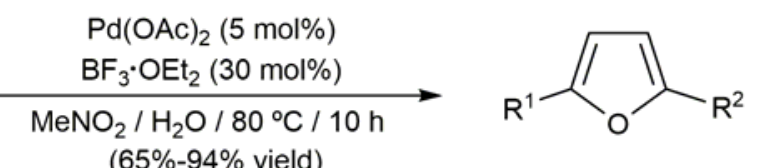

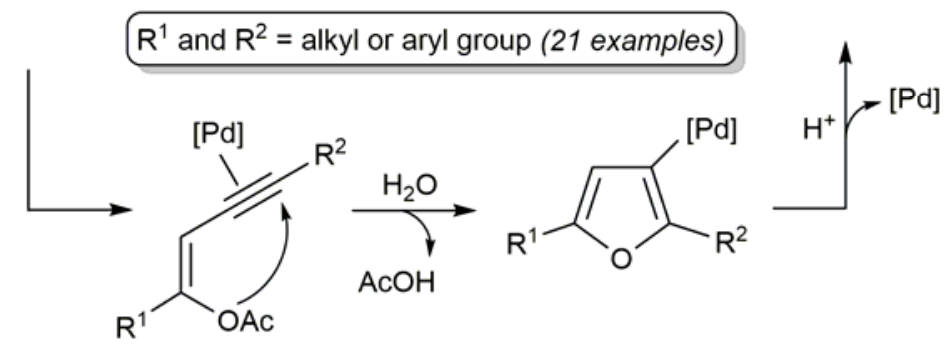

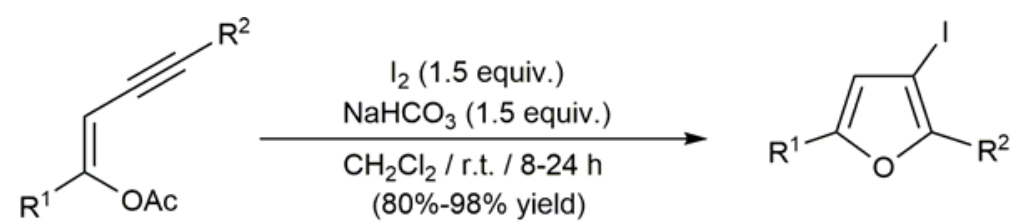
(80\%-98\% yield)

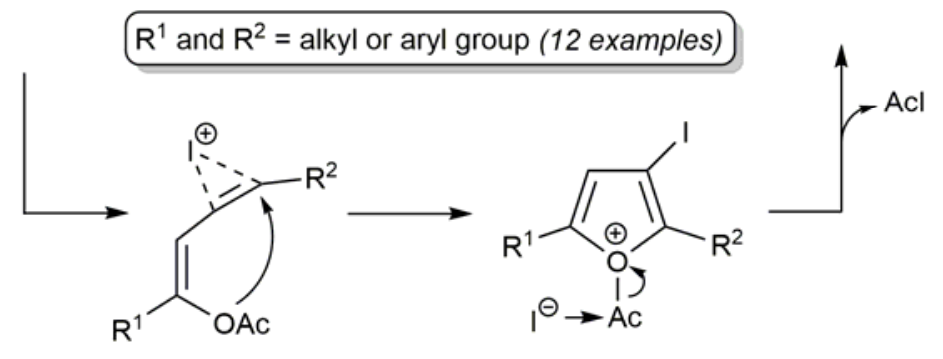<smiles>[R]C#CC([R])=C([R])O[Na]</smiles><smiles>[R]C#CC([R])=C([R])OC(C)=O</smiles>

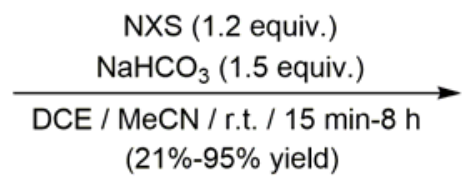<smiles>[R]c1oc([R])c([X])c1[R]</smiles>

$\mathrm{R}^{1}=$ aryl group; $\mathrm{R}^{2}$ and $\mathrm{R}^{3}=$ alkyl or aryl group; $\mathrm{X}=\mathrm{Br}, \mathrm{I}$ (26 examples)

Scheme 20. Some furan-ring formation reactions employing enynyl acetates as precursors.

Contrary to the case of the Suzuki-Miyaura and Sonogashira reactions, the participation of $\beta$-haloenol esters in Negishi- and Kumada-Corriu-type cross-coupling processes remains almost unexplored. In fact, only the examples depicted in Scheme 21 can be currently found in the literature [61,64].

On the other hand, homocoupling reactions of alkenyl halides have been extensively studied during the last decades since they provide a straightforward access to conjugated 1,3-dienes and polyenes [82]. In this context, taking advantage of previous works by Takagi and coworkers with non-functionalized alkenyl halides [83-85], an efficient and broad scope protocol for the homocoupling of (Z)- $\beta$-iodoenol esters 41 was developed by Francos and Cadierno (Scheme 22) [86]. The process, which is catalyzed by nickel(0) species generated in situ by combining $\left[\mathrm{NiCl}_{2}\left(\mathrm{PPh}_{3}\right)_{2}\right]$ with $\mathrm{NaI}$ and $\mathrm{Zn}$ dust, afforded the buta-1,3-diene-1,4-diyl diester products 42 as the corresponding ZZ-isomers exclusively. It is also 
worth noting that 1,3-dienes 42 proved to be useful precursors for the preparation of synthetically relevant $C_{2}$ symmetric 1,4-diols 43 , through a rhodium-catalyzed asymmetric hydrogenation of the two $\mathrm{C}=\mathrm{C}$ bonds of $\mathbf{4 2}$ and a subsequent base-promoted deacylation reaction [87].
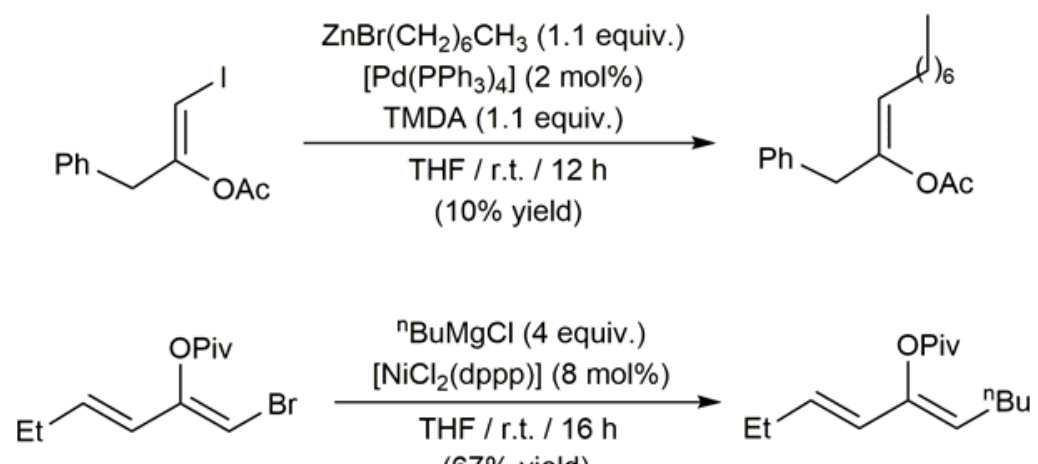

(67\% yield)

Scheme 21. Negishi- and Kumada-Corriu cross-coupling reactions involving $\beta$-haloenol esters.<smiles>[R]C(=O)O/C([R])=C\I</smiles>

41

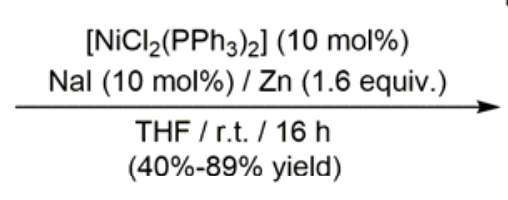

THF / r.t. / $16 \mathrm{~h}$

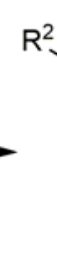<smiles>[R]C=CC=CCC([R])O</smiles>

43

$$
\begin{aligned}
& R^{1}=\text { alkyl or aryl group } \\
& R^{2}=\text { alkyl, aryl, heteroaryl or alkenyl group (33 examples) }
\end{aligned}
$$

Scheme 22. Ni-catalyzed homocoupling of (Z)- $\beta$-iodoenol esters.

Acyclic $\beta$-haloenol esters have also been employed as starting materials for the generation of heterocyclic systems. In this context, the intramolecular palladium-catalyzed Mizoroki-Heck coupling of the (Z)- $\beta$-iodoenol cinnamates 20 allowed the preparation of furanones $\mathbf{4 4}$ in moderate to high yields (Scheme 23) [63].<smiles>[R]/C(=C/I)OC(=O)/C=C/[Al]</smiles>
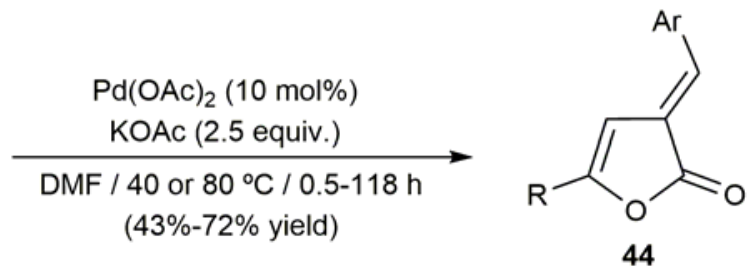

$$
\begin{aligned}
& \mathrm{R}=\mathrm{Ph}, 2-\mathrm{Naphthyl}_{1} n-\mathrm{C}_{6} \mathrm{H}_{13} ; \mathrm{Ar}=4-\mathrm{C}_{6} \mathrm{H}_{4} \mathrm{OMe} \\
& \mathrm{R}=\mathrm{Ph}, 4-\mathrm{C}_{6} \mathrm{H}_{4} \mathrm{Br}, 2-\mathrm{Naphthyl}, n-\mathrm{C}_{6} \mathrm{H}_{13}, \mathrm{Cy}, c-\mathrm{C}_{3} \mathrm{H}_{5} ; \mathrm{Ar}=\mathrm{Ph} \\
& \mathrm{R}=\mathrm{Ph}, n-\mathrm{C}_{6} \mathrm{H}_{13}, c-\mathrm{C}_{3} \mathrm{H}_{5} ; \mathrm{Ar}=4-\mathrm{C}_{6} \mathrm{H}_{4} \mathrm{Me} \\
& \mathrm{R}=\mathrm{Ph}, 4-\mathrm{C}_{6} \mathrm{H}_{4} \mathrm{Br}, n-\mathrm{C}_{6} \mathrm{H}_{13} ; \mathrm{Ar}=2-\mathrm{Thienyl} \\
& \mathrm{R}=3,4-\mathrm{C}_{6} \mathrm{H}_{3}(\mathrm{OAC})_{2} ; \mathrm{Ar}=3,4-\mathrm{C}_{6} \mathrm{H}_{3}(\mathrm{OAc})_{2}
\end{aligned}
$$

Scheme 23. Intramolecular Mizoroki-Heck coupling of (Z)- $\beta$-iodoenol cinnamates.

A broad scope protocol for the synthesis of 3-substituted isocoumarins $\mathbf{4 6}$ by coupling of bromoalkynes with benzoic acids, catalyzed by palladium(II) trifluoroacetate in combination with the diphosphine ligand DPEPhos (bis[2-(diphenylphosphino)phenyl] ether) and $\mathrm{K}_{2} \mathrm{CO}_{3}$, was described by $\mathrm{Wu}$, Jiang and co-workers (Scheme 24) [88]. A reaction pathway involving the initial anti addition of 
the acid to the alkyne, and subsequent oxidative annulation of the resulting $\beta$-bromoenol benzoates 45 , was proposed by the authors.

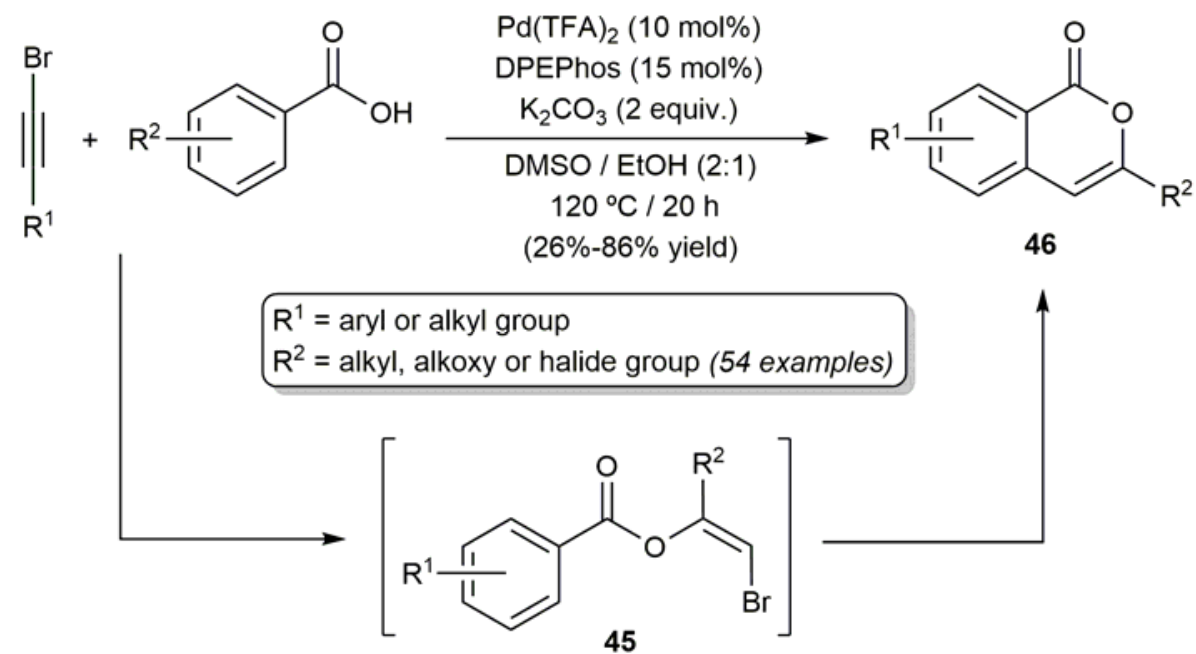

Scheme 24. Catalytic synthesis of isocoumarins from bromoalkynes and benzoic acids.

(Z)- $\beta$-Halenol acetates proved to be also useful starting materials for the preparation of symmetrical 2,5-disubstituted pyrazines 47 (Scheme 25) [89]. Although the formation of compounds 47 was initially observed in the reactions of the haloenol acetates with an ammonia solution under palladium/copper-catalyzed conditions, a more detailed investigation showed that no metal sources are really needed for the reaction to proceed, and that any source of ammonia can be employed. In this regard, employing ammonium formate, and performing the reaction in $\mathrm{DMF}$ at $120^{\circ} \mathrm{C}$, a wide range of 2,5-disubstituted pyrazines could be accessed in moderate to excellent yields starting from both aromatic and aliphatic (Z)- $\beta$-iodoenol or (Z)- $\beta$-bromoenol acetates (Scheme 25$)$. The regioselectivity of the process was excellent, the formation of the corresponding 2,6-disubtituted regioisomers being not observed under these optimized conditions. According to the authors, $\alpha$-halomethyl ketones could be involved as intermediates.

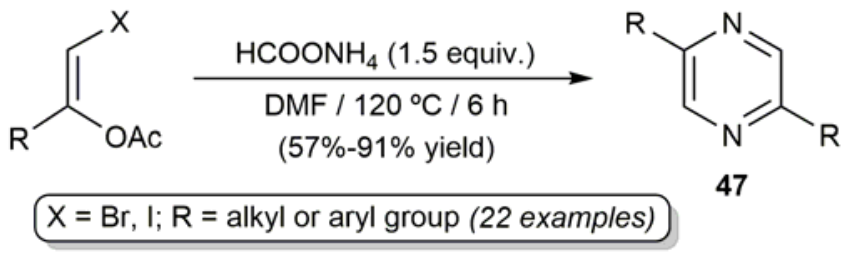

Scheme 25. Synthesis of 2,5-disubstituted pyrazines from (Z)- $\beta$-haloenol acetates.

\subsection{Cyclic $\beta$-Haloenol Esters}

Although to a much lesser extent, the participation of haloenol lactones in metal-catalyzed cross-coupling reactions has also been described. In this regard, several 5- and 6-membered ring ynenol lactones, including some optically pure representatives, could be accessed from the corresponding iodoenol lactones via classical Pd-catalyzed Sonogashira coupling reactions (Figure 6) [41,44,90,91]. Interestingly, these compounds featured biological activity as enzymes inhibitors [44,90,91]. 

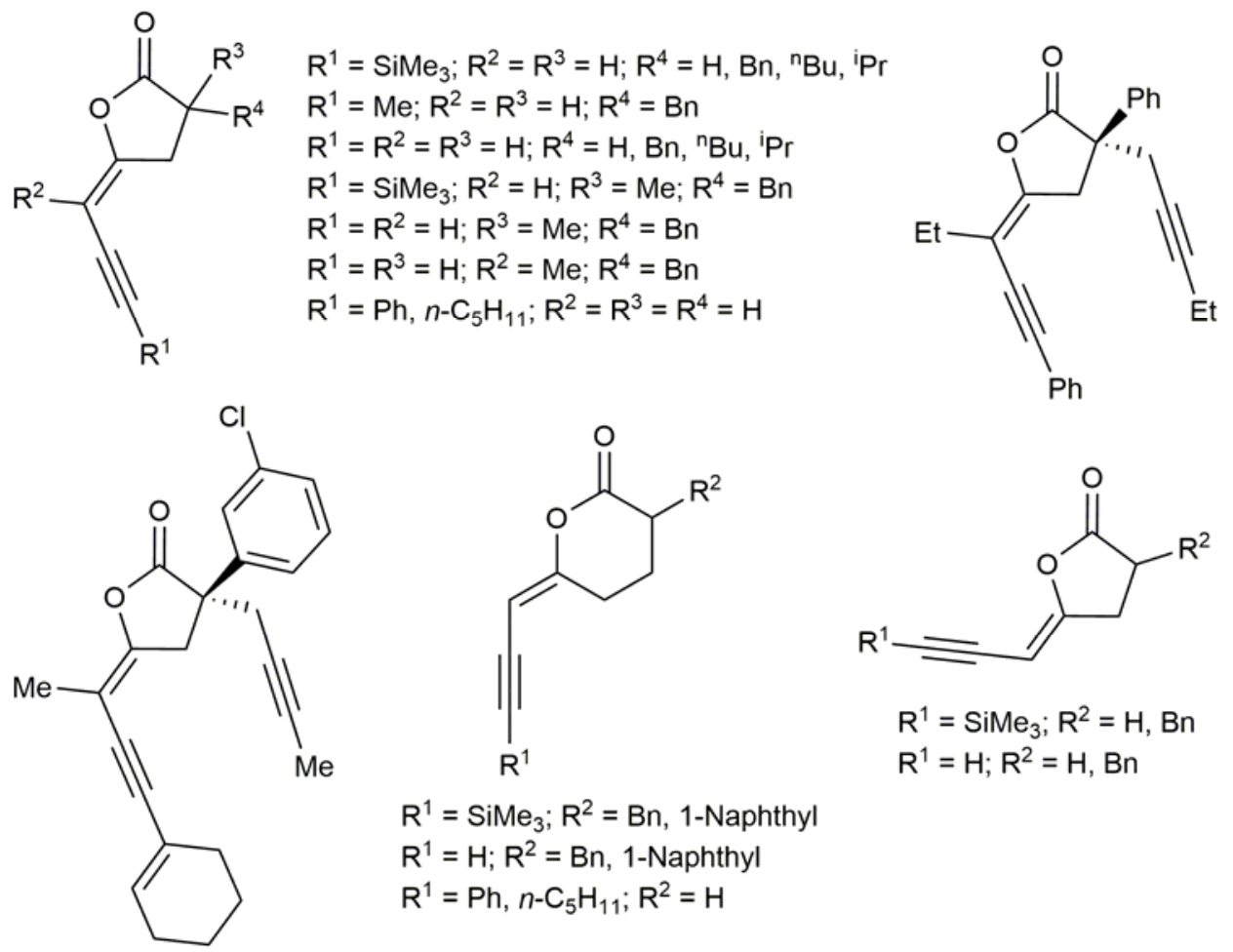

Figure 6. Ynenol lactones synthesized by Sonogashira coupling of the respective iodoenol lactones with terminal alkynes.

Additionally, Hennecke and coworkers reported the synthesis of the arylenol lactones 49 by Negishi coupling of the iodoenol derivative $\mathbf{4 8}$ with the corresponding arylzinc chloride catalyzed by [ $\left.\mathrm{PdCl}_{2}(\mathrm{dppf})\right]\left(\mathrm{dppf}=1,1^{\prime}\right.$-bis(diphenylphosphino)ferrocene) (Scheme 26) [44]. The use of [ $\mathrm{PdCl}_{2}$ (dppf)] as catalyst proved to be crucial, since other palladium sources, i.e., PEPPSI-type catalysts or the $\left[\mathrm{Pd}_{2}(\mathrm{dba})_{3}\right] /$ trisfurylphosphine combination, led to the extensive dehalogenation of 48 . Additionally, of note is the fact that attempts to generate compounds 49 through Pd-catalyzed Suzuki-Miyaura coupling of $\mathbf{4 8}$ with aryl boronic acids failed, due to the incompatibility of the iodoenol moiety with the basic conditions required in this particular cross-coupling process [44].
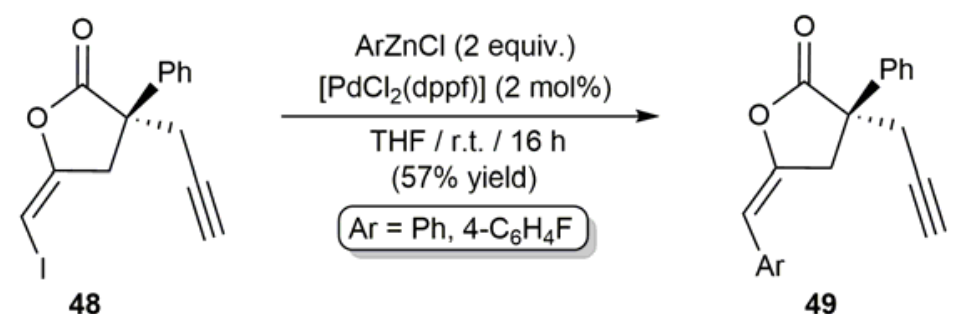

Scheme 26. Access to arylenol lactones by Negishi coupling.

\section{Conclusions}

In this contribution we summarized the catalytic protocols currently known for the preparation of $\beta$-haloenol esters and haloenol lactones, a particular class of haloalkenes, which are gaining significance as coupling partners in diverse chemical transformations of synthetic interest. Metal-catalyzed reactions in which these functionalized olefins participate as substrates, mainly palladium-catalyzed $\mathrm{C}-\mathrm{C}$ cross-coupling processes, were also discussed. Most of the works herein presented have been published during the last decade, demonstrating the current interest on the use of these molecules as building blocks in organic synthesis. Although there is already a body of work in the field, it still 
remains open and new synthetic approaches to these compounds and applications can be expected in the near future.

Funding: Financial support from the Spanish Ministry of Economy, Industry and Competitiveness (MINECO project CTQ2016-75986-P) is gratefully acknowledged.

Conflicts of Interest: The author declares no conflict of interest.

\section{References}

1. De Meijer, A.; Diederich, F. (Eds.) Metal-Catalyzed Cross-Coupling Reactions; Wiley-VCH: Weinheim, Germany, 2004.

2. Nicolaou, K.C.; Bulger, P.G.; Sarlah, D. Palladium-catalyzed cross-coupling reactions in total synthesis. Angew. Chem. Int. Ed. 2005, 44, 4442-4489. [CrossRef]

3. Schlosser, M. (Ed.) Organometallics in Synthesis; John Wiley \& Sons: Hoboken, NJ, USA, 2013.

4. Jeschke, J.; Gäbler, C.; Lang, H. Regioselective formation of enol esters from the ruthenium-catalyzed Markovnikov addition of carboxylic acids to alkynes. J. Org. Chem. 2016, 81, 476-484. [CrossRef]

5. Francos, J.; Cadierno, V. Metal-catalyzed intra- and intermolecular addition of carboxylic acids to alkynes in aqueous media: A review. Catalysts 2017, 7, 328. [CrossRef]

6. González-Liste, P.J.; Francos, J.; García-Garrido, S.E.; Cadierno, V. The intermolecular hydro-oxycarbonylation of internal alkynes: Current state of the art. Arkivoc 2018, 2, 17-39.

7. Takai, K.; Kokumai, R.; Nobunaka, T. Reactions of coordinated geminal dichromium reagents with aldehydes: Stereoselective formation of (Z)-2-chloroalk-2-en-1-ols. Chem. Commun. 2001, 1128-1129. [CrossRef]

8. Bejot, R.; Tisserand, S.; Reddy, L.M.; Barma, D.K.; Baati, R.; Falck, J.R.; Mioskowski, C. Stereoselective transformations of trihalomethylcarbinols induced by chromous chloride. Angew. Chem. Int. Ed. 2005, 44, 2008-2011. [CrossRef]

9. Bejot, R.; Anjaiah, S.; Falck, J.R.; Mioskowski, C. $\alpha$-Haloenol acetates: Versatile reactants for oxetan-2-one, azetidin-2-one and isoxazolidin-5-one synthesis. Eur. J. Org. Chem. 2007, 101-107. [CrossRef]

10. Kashinath, D.; Mioskowski, C.; Falck, J.R.; Goli, M.; Meunier, S.; Baati, R.; Wagner, A. Highly stereoselective synthesis of $(Z, E)$-1-halo-1,3-dienol esters via rearrangement of Fischer chromium chloro-carbenes using microwave irradiation. Org. Biomol. Chem. 2009, 7, 1771-1774. [CrossRef]

11. Joshi, G.C.; Chambers, W.D.; Warnhoff, E.W. Camphor enol and homoenol acetates. Tetrahedron Lett. 1967, 8, 3613-3617. [CrossRef]

12. Kowalski, C.J.; O'Dowd, M.L.; Burke, M.C.; Fields, K.W. $\alpha$-Ketodianions. New reactive intermediates. J. Am. Chem. Soc. 1980, 102, 5411-5412. [CrossRef]

13. Kowalski, C.J.; Haque, M.S.; Fields, K.W. Ester homologation via $\alpha$-bromo $\alpha$-keto dianion rearrangement. J. Am. Chem. Soc. 1985, 107, 1429-1430. [CrossRef]

14. Kowalski, C.J.; Haque, M.S. Bromomethyl ketones and enolates: Alternative products from ester homologation reactions. J. Org. Chem. 1985, 50, 5140-5142. [CrossRef]

15. Kowalski, C.J.; Reddy, R.E. Ester homologation revisited: A reliable, higher yielding and better understood procedure. J. Org. Chem. 1992, 57, 7194-7208. [CrossRef]

16. Barluenga, J.; Rodríguez, M.A.; González, J.M.; Campos, P.J. A new electrophilic addition to acetylenes. Synthesis of 1,2-iodofunctionalized olefins. Tetrahedron Lett. 1986, 27, 3303-3306. [CrossRef]

17. Barluenga, J.; Rodríguez, M.A.; Campos, P.J. Synthesis of 2-functionalized 1,1-diiodo-1-alkenes. Generation and reactions of 1-iodo-1-lithio-1-alkenes and 1,1-dilithio-1-alkenes. J. Am. Chem. Soc. 1988, 110, 5567-5568. [CrossRef]

18. Barluenga, J.; Rodríguez, M.A.; Campos, P.J. Synthesis of 2-functionalized 1-chloro-1-iodo-1-alkenes from 1-chloro-1-alkynes and $\mathrm{IPy}_{2} \mathrm{BF}_{4}$. Tetrahedron Lett. 1990, 31, 2751-2754. [CrossRef]

19. Barluenga, J.; Rodríguez, M.A.; Campos, P.J. Electrophilic additions of positive iodine to alkynes through an iodonium mechanism. J. Org. Chem. 1990, 55, 3104-3106. [CrossRef]

20. Barluenga, J.; Rodríguez, M.A.; Campos, P.J. Stereoselective synthesis of 2-functionalized 1-bromo-1-iodo-1-alkenes by electrophilic iodination of 1-bromo-1-alkynes. Synthesis 1992, 270-272. [CrossRef]

21. Pincock, J.A.; Yates, K. Kinetics and mechanism of electrophilic bromination of acetylenes. Can. J. Chem. 1970, 48, 3332-3348. [CrossRef] 
22. Ogata, Y.; Urasaki, I. The reaction of tolan with a mixture of iodine and peracetic acid. J. Org. Chem. 1971, 36, 2164-2168. [CrossRef]

23. Yates, K.; Go, T.A. Vinyl cation intermediates in electrophilic additions to triple bonds. 2. Chlorination of alkylacetylenes. J. Org. Chem. 1980, 45, 2385-2391. [CrossRef]

24. Heasley, G.E.; Codding, C.; Sheehy, J.; Gering, K.; Heasley, V.L.; Shellhamer, D.F.; Rempel, T. Chlorination of 1-hexyne and 3-hexyne in acetic acid and methanol. J. Org. Chem. 1985, 50, 1773-1776. [CrossRef]

25. Hokamp, T.; Storm, A.T.; Yusubov, M.; Wirth, T. Iodine monoacetate for efficient oxyiodinations of alkenes and alkynes. Synlett 2018, 29, 415-418.

26. Jovtscheff, A.; Spassov, S.L. Heterolytische anlagerung an acetylen-verbindungen I: Stereochemie und kinetik der anlagerung im system diphenylacetylen-N-brom-succinimid-essigsäure-wasser. Monatsh. Chem. 1967, 98, 2272-2281. [CrossRef]

27. Jovtscheff, A.; Spassov, S.L. Heterolytische anlagerungen an acetylen-verbindungen III: Über den mechanismus der umsetzung von acetylen-verbindungen mit $N$-bromsuccinimid in eisessig oder waßriger essigsäure. Monatsh. Chem. 1969, 100, 328-341. [CrossRef]

28. Okamoto, N.; Miwa, Y.; Minami, H.; Takeda, K.; Yanada, R. Regio- and stereoselective multisubstituted enol ester synthesis. J. Org. Chem. 2011, 76, 9133-9138. [CrossRef] [PubMed]

29. Merkushev, E.B.; Karpitskaya, L.G.; Novosel'tseva, G.I.; Raida, V.S. Conjugated iodoacetoxylation of triple bonds. Izv. Akad. Nauk Ser. Khim. 1978, 1153-1154. [CrossRef]

30. Xia, X.-F.; Gu, Z.; Liu, W.; Wang, N.; Wang, H.; Xia, Y.; Gao, H.; Liu, X. Selective oxygenation of alkynes: A direct approach to diketones and vinyl acetate. Org. Biomol. Chem. 2014, 12, 9909-9913. [CrossRef]

31. Priebbenow, D.L.; Gable, R.W.; Baell, J. Regio- and stereoselective iodoacyloxylations of alkynes. J. Org. Chem. 2015, 80, 4412-4418. [CrossRef]

32. Crespo, L.T.C.; Nogueira, G.P.; de Mattos, M.C.S.; Esteves, P.M. Reaction of trihaloisocyanuric acids with alkynes: An efficient methodology for the preparation of $\beta$-haloenol acetates. Arkivoc 2018, 2, $205-214$. [CrossRef]

33. Chawla, R.; Singh, A.K.; Yadav, L.D.S. Catalyst- and metal-free rapid functionalizations of alkynes using $\mathrm{TsNBr}_{2}$. Synlett 2013, 24, 1558-1562.

34. Daniels, S.B.; Cooney, E.; Sofia, M.J.; Chakravarty, P.K.; Katzenellenbogen, J.A. Haloenol lactones: Potent enzyme-activated irreversible inhibitors for $\alpha$-chymotrypsin. J. Biol. Chem. 1983, 258, 15046-15053. [PubMed]

35. Sofia, M.J.; Katzenellenbogen, J.A. Enol lactone inhibitors of serine proteases. The effect of regiochemistry on the inactivation behavior of phenyl-substituted (halomethylene)tetra- and -dihydrofuranones and (halomethylene)tetrahydropyranones toward $\alpha$-chymotrypsin: Stable acyl enzyme intermediate. J. Med. Chem. 1986, 29, 230-238. [PubMed]

36. Rai, R.; Katzenellenbogen, J.A. Guanidinophenyl-substituted enol lactones as selective, mechanism-based inhibitors of trypsin-like serine proteases. J. Med. Chem. 1992, 35, 4150-4159. [CrossRef]

37. Wu, Z.; Minhas, G.S.; Wen, D.; Jiang, H.; Chen, K.; Zimniak, P.; Zheng, J. Design, synthesis, and structure-activity relationships of haloenol lactones: Site-directed and isozyme-selective glutathione $S$-transferase inhibitors. J. Med. Chem. 2004, 47, 3282-3294. [CrossRef]

38. Mock, J.N.; Taliaferro, J.P.; Lu, X.; Patel, S.K.; Cummings, B.S.; Long, T.E. Haloenol pyranones and morpholinones as antineoplastic agents. Bioorg. Med. Chem. Lett. 2012, 22, 4854-4858. [CrossRef]

39. Albrecht, L.; Albrecht, A.; Janecki, T. $\alpha$-Alkylidene- $\gamma$ - and $\delta$-lactones and lactams. In Natural Lactones and Lactams: Synthesis, Occurrence and Biological Activity; Janecki, T., Ed.; Wiley-VCH: Weinheim, Germany, 2013; pp. 147-192.

40. Ranganathan, S.; Muraleedharan, K.M.; Vaish, N.K.; Jayaraman, N. Halo- and selenolactonisation: The two major strategies for cyclofunctionalisation. Tetrahedron 2004, 60, 5273-5308. [CrossRef]

41. Halder, J.; Das, D.; Nanda, S. A distinctive transformation based diversity oriented synthesis of small ring carbocycles and heterocycles from biocatalytically derived enantiopure $\alpha$-substituted- $\beta$-hydroxyesters. Org. Biomol. Chem. 2018, 16, 2549-2575. [CrossRef]

42. Wilking, M.; Mück-Lichtenfeld, C.; Daniliuc, C.G.; Hennecke, U. Enantioselective, desymmetrizing bromolactonization of alkynes. J. Am. Chem. Soc. 2013, 135, 8133-8136. [CrossRef]

43. Wilking, M.; Daniliuc, C.G.; Hennecke, U. Monomeric cinchona alkaloid-based catalysts for highly enantioselective bromolactonisation of alkynes. Chem. Eur. J. 2016, 22, 18601-18607. [CrossRef] 
44. Fricke, C.; Wilking, M.; Daniliuc, C.G.; Hennecke, U. An enantioselective iodolactonization/cross-coupling protocol for the synthesis of highly substituted enol lactones. Eur. J. Org. Chem. 2018, 3158-3166. [CrossRef]

45. Wu, W.; Jiang, H. Haloalkynes: A powerful and versatile building block in organic synthesis. Acc. Chem. Res. 2014, 47, 2483-2504. [CrossRef] [PubMed]

46. Petko, D.; Koh, S.; Tam, W. Transition metal-catalyzed reactions of alkynyl halides. Curr. Org. Synth. 2019, 16, 546-582. [CrossRef] [PubMed]

47. Cadierno, V. Metal-catalyzed hydrofunctionalization reactions of haloalkynes. Eur. J. Inorg. Chem. 2020, 886-898. [CrossRef]

48. Uemura, S.; Tara, H.; Okano, M.; Ichikawa, K. Acetoxythallation of acetylenes and the proto- and halogenodethallation of the products. Bull. Chem. Soc. Jpn. 1974, 47, 2663-2671. [CrossRef]

49. Amos, R.A.; Katzenellenbogen, J.A. An efficient synthesis of $\gamma$-methylene- $\gamma$-butyrolactone ( $\alpha^{\prime}$-angelicalactone). Application to the synthesis of deoxyobtusilactone and deoxyisoobtusilactone. J. Org. Chem. 1978, 43, 560-564. [CrossRef]

50. Krafft, G.A.; Katzenellenbogen, J.A. Synthesis of halo enol lactones. Mechanism-based inactivators of serine proteases. J. Am. Chem. Soc. 1981, 103, 5459-5466. [CrossRef]

51. Spencer, R.W.; Tam, F.T.; Thomas, E.; Robinson, V.J.; Krantz, A. Ynenol lactones: Synthesis and investigation of reactions relevant to their inactivation of serine proteases. J. Am. Chem. Soc. 1986, 108, 5589-5597. [CrossRef]

52. Barluenga, J.; Martínez-Gallo, J.M.; Nájera, C.; Yus, M. Stereoselective bifunctionalization of alkynes by means of the mercury(II) salt-iodine combination. J. Chem. Soc. Perkin Trans. 1 1987, 1017-1019. [CrossRef]

53. Dai, W.; Katzenellenbogen, J.A. Stereoselective Z- and E-bromo enol lactonization of alkynois acids. J. Org. Chem. 1991, 56, 6893-6896. [CrossRef]

54. Chen, Z.; Li, J.; Jiang, H.; Zhu, S.; Li, Y.; Qi, C. Silver-catalyzed difunctionalization of terminal alkynes: Highly regio- and stereoselective synthesis of (Z)- $\beta$-haloenol acetates. Org. Lett. 2010, 12, 3262-3265. [CrossRef] [PubMed]

55. Genin, E.; Toullec, P.Y.; Antoniotti, S.; Brancour, C.; Genêt, J.-P.; Michelet, V. Room temperature Au(I)-catalyzed exo-selective cycloisomerization of acetylenic acids: An entry to functionalized $\gamma$-lactones. J. Am. Chem. Soc. 2006, 128, 3112-3113. [CrossRef] [PubMed]

56. Harkat, H.; Weibel, J.-M.; Pale, P. A mild access to $\gamma$-and $\delta$-alkylidene lactones through gold catalysis. Tetrahedron Lett. 2006, 47, 6273-6276. [CrossRef]

57. Harkat, H.; Dembelé, A.Y.; Weibel, J.-M.; Blanc, A.; Pale, P. Cyclization of alkynoic acids with gold catalysts: A surprising dichotomy between $\mathrm{Au}^{\mathrm{I}}$ and $\mathrm{Au}^{\mathrm{III}}$. Tetrahedron 2009, 65, 1871-1879. [CrossRef]

58. Gasperini, D.; Maggi, L.; Dupuy, S.; Veenboer, R.M.P.; Cordes, D.B.; Slawin, A.M.Z.; Nolan, S.P. Gold(I)-catalysed cyclisation of alkynoic acids: Towards an efficient and eco-friendly synthesis of $\gamma-, \delta$ - and $\varepsilon$-lactones. Adv. Synth. Catal. 2016, 358, 3857-3862. [CrossRef]

59. González-Liste, P.J.; León, F.; Arribas, I.; Rubio, M.; García-Garrido, S.E.; Cadierno, V.; Pizzano, A. Highly stereoselective synthesis and hydrogenation of (Z)-1-alkyl-2-arylvinyl acetate: A wide scope procedure for the preparation of chiral homobenzylic esters. ACS Catal. 2016, 6, 3056-3060. [CrossRef]

60. González-Liste, P.J.; Francos, J.; García-Garrido, S.E.; Cadierno, V. Gold-catalyzed regio- and stereoselective addition of carboxylic acids to iodoalkynes: Access to (Z)- $\beta$-iodoenol esters and 1,4-disubstituted (Z)-enynyl esters. J. Org. Chem. 2017, 82, 1507-1516. [CrossRef]

61. León, F.; González-Liste, P.J.; García-Garrido, S.E.; Arribas, I.; Rubio, M.; Cadierno, V.; Pizzano, A. Broad scope synthesis of esters precursors of nonfunctionalized chiral alcohols based on the asymmetric hydrogenation of $\alpha, \beta$-dialkyl-, $\alpha, \beta$-diaryl-, and $\alpha$-alkyl- $\beta$-aryl-vinyl esters. J. Org. Chem. 2017, 82, 5852-5867. [CrossRef]

62. Hashmi, A.S.K.; Toste, F.D. (Eds.) Modern Gold Catalyzed Synthesis; Wiley-VCH: Weinheim, Germany, 2012.

63. Muthusamy, G.; Pansare, S.V. Stereoselective synthesis of E-3-(arylmethylidene)-5-(alkyl/aryl)-2(3H)-furanones by sequential hydroacyloxylation-Mizoroki-Heck reactions of iodoalkynes. Org. Biomol. Chem. 2018, 16, 7971-7983. [CrossRef]

64. Wang, Y.; Lu, B.; Zhang, L. The use of $\mathrm{Br} / \mathrm{Cl}$ to promote regioselective gold-catalyzed rearrangement of propargylic carboxylates: An efficient synthesis of (1Z,3E)-1-bromo/cloro-2-carboxy-1,3-dienes. Chem. Commun. 2010, 46, 9179-9181. [CrossRef] 
65. Jiang, J.; Liu, Y.; Hou, C.; Li, Y.; Luan, Z.; Zhao, C.; Ke, Z. Rationalization of the selectivity between 1,3- and 1,2-migration: A DFT study on gold(I)-catalyzed propargylic ester rearrangement. Org. Biomol. Chem. 2016, 14, 3558-3563. [CrossRef] [PubMed]

66. Ghosh, N.; Nayak, S.; Prabagar, B.; Sahoo, A.K. Regioselective hydration of terminal halo-substituted propargyl carboxylates by gold catalyst: Synthesis of $\alpha$-acyloxy $\alpha^{\prime}$-halo ketones. J. Org. Chem. 2014, 79, 2453-2462. [CrossRef] [PubMed]

67. Lin, J.; Wu, Y.; Zhao, X. Theoretical insight into the Au(I)-catalyzed hydration of halo-substituted propargyl acetate: Dynamic water-assisted mechanism. RSC Adv. 2016, 6, 89836-89846.

68. Chen, Z.-W.; Ye, D.-N.; Ye, M.; Zhou, Z.-G.; Li, S.-H.; Liu, L.-X. AgF/TFA-promoted highly efficient synthesis of $\alpha$-haloketones from haloalkynes. Tetrahedron Lett. 2014, 55, 1373-1375. [CrossRef]

69. Zeng, M.; Huang, R.-X.; Li, W.-Y.; Liu, X.-W.; He, F.-L.; Zhang, Y.-Y.; Xiao, F. In(OTf) $3 /$ acid co-catalyzed hydration of 1-haloalkynes to $\alpha$-halomethyl ketones. Tetrahedron 2016, 72, 3818-3822. [CrossRef]

70. Zou, H.; He, W.; Dong, Q.; Wang, R.; Yi, N.; Jiang, J.; Pen, D.; He, W. First catalyzed hydration of haloalkynes by a recyclable catalytic system. Eur. J. Org. Chem. 2016, 116-121. [CrossRef]

71. Chen, X.; Chen, D.; Lu, Z.; Kong, L.; Zhu, G. Palladium-catalyzed coupling of haloalkynes with allyl acetate: A regio- and stereoselective synthesis of (Z)- $\beta$-haloenol acetates. J. Org. Chem. 2011, 76, 6338-6343. [CrossRef]

72. Espinosa-Jalapa, N.A.; Ke, D.; Nebra, N.; Le Goanvic, L.; Mallet-Ladeira, S.; Monot, J.; Martin-Vaca, B.; Bourissou, D. Enhanced catalytic performance of indenediide palladium pincer complexes for cycloisomerization: Efficient synthesis of alkylidene lactams. ACS Catal. 2014, 4, 3605-3611. [CrossRef]

73. Monot, J.; Brunel, P.; Kefalidis, C.E.; Espinosa-Jalapa, N.A.; Maron, L.; Martin-Vaca, B.; Bourissou, D. A case study of proton shuttling in palladium catalysis. Chem. Sci. 2016, 7, 2179-2187. [CrossRef]

74. Abe, S.; Miyaura, N.; Suzuki, A. The palladium-catalyzed cross-coupling reaction of enol acetates with 1-alkenyl-, aryl-, or alkylboron compounds; A facile synthesis of ketones and their enol acetates. Bull. Chem. Soc. Jpn. 1992, 65, 2863-2865. [CrossRef]

75. He, R.; Deng, M.-Z. A novel method for the construction of $(Z, E)$ - or $(Z, Z)$-conjugated alkadienyl carboxylates. Org. Lett. 2002, 4, 2759-2762. [CrossRef] [PubMed]

76. Chen, Z.; Huang, G.; Jiang, H.; Huang, H.; Pan, X. Synthesis of 2,5-disubstituted 3-iodofurans via palladium-catalyzed coupling and iodocyclization of terminal alkynes. J. Org. Chem. 2011, 76, 1134-1139. [CrossRef] [PubMed]

77. Okamoto, N.; Yanada, R. Multisubstituted furan formation from (Z)- or (E)-enynyl acetates: Tandem reactions accelerated by electron-donating groups on aromatic rings. J. Org. Chem. 2012, 77, 3944-3951. [CrossRef] [PubMed]

78. Chen, Z.W.; Chen, H.-C.; Ye, D.-N.; Hu, Q.-S. (Z)-1,4-Diphenylbut-1-en-3-ynyl acetate. Acta Cryst. 2012, E68, o2847. [CrossRef] [PubMed]

79. Chen, Z.-W.; Luo, M.-T.; Wen, Y.-L.; Ye, M.; Zhou, Z.-G.; Liu, L.-X. A highly efficient synthesis of 2,5-disubstituted furans from enyne acetates catalyzed by Lewis acid and palladium. Synlett 2014, 25, 2341-2344. [CrossRef]

80. Lee, H.; Yi, Y.; Jun, C.-H. Copper(II)-promoted, one-pot conversion of 1-alkynes with anhydrides or primary amines to the respective 2,5-disubstituted furans or pyrroles under microwave irradiation conditions. Adv. Synth. Catal. 2015, 357, 3485-3490. [CrossRef]

81. Okamoto, N.; Sueda, T.; Yanada, R. Tandem reaction of enynyl acetate: Precursor of allenyl ketones. Chem. Pharm. Bull. 2016, 64, 941-946. [CrossRef]

82. Stefani, H.A.; Guarezemini, A.S.; Cella, R. Homocoupling reactions of alkynes, alkenes and alkyl compounds. Tetrahedron 2010, 66, 7871-7918. [CrossRef]

83. Takagi, K.; Hayama, N.; Sasaki, K. Ni(0)-trialkylphosphine complexes. Efficient homo-coupling catalyst for aryl, alkenyl, and heteroaromatic halides. Bull. Chem. Soc. Jpn. 1984, 57, 1887-1890. [CrossRef]

84. Takagi, K.; Mimura, H.; Inokawa, S. The in situ-generated nickel(0)-catalyzed homo-coupling of alkenyl halides with zinc powder. A specific outcome in stereochemistry. Bull. Chem. Soc. Jpn. 1984, 57, 3517-3522. [CrossRef]

85. Sasaki, K.; Nakao, K.; Kobayashi, Y.; Sakai, M.; Uchino, N.; Sakakibara, Y.; Takagi, K. Ni(0)-triphenylphosphine complex-catalyzed homo-coupling of 1-alkenyl halides with zinc powder. Bull. Chem. Soc. Jpn. 1993, 66, 2446-2448. [CrossRef]

86. Francos, J.; Cadierno, V. Nickel-catalyzed homocoupling of ( $Z$ )- $\beta$-iodoenol esters: Stereoselective access to (Z,Z)-buta-1,3-diene-1,4-diyl diesters. Synthesis 2019, 51, 3117-3126. [CrossRef] 
87. León, F.; Francos, J.; López-Serrano, J.; García-Garrido, S.E.; Cadierno, V.; Pizzano, A. Double asymmetric hydrogenation of conjugated dienes: A self-breeding chirality route to $C_{2}$ symmetric 1,4 -diols. Chem. Commun. 2019, 55, 786-789. [CrossRef] [PubMed]

88. Jiang, G.; Li, J.; Zhu, C.; Wu, W.; Jiang, H. Palladium-catalyzed sequential nucleophilic addition/oxidative annulation of bromoalkynes with benzoic acids to construct functionalized isocoumarins. Org. Lett. 2017, 19, 4440-4443. [CrossRef]

89. Chen, Z.; Ye, D.; Xu, G.; Ye, M.; Liu, L. Highly efficient synthesis of 2,5-disubstituted pyrazines from (Z)- $\beta$-haloenol acetates. Org. Biomol. Chem. 2013, 11, 6699-6702. [CrossRef]

90. Tam, F.T.; Spencer, R.W.; Thomas, E.M.; Copp, L.J.; Krantz, A. Novel suicide inhibitors of serine proteinases. Inactivation of human leukocyte elastase by ynenol lactones. J. Am. Chem. Soc. 1984, 106, 6849-6851. [CrossRef]

91. Zupan, L.A.; Weiss, R.H.; Hazen, S.L.; Parnas, B.L.; Aston, K.W.; Lennon, P.j.; Getman, D.P.; Gross, R.W. Structural determinants of haloenol lactone-mediated suicide inhibition of canine myocardial calcium-independent phospholipase A2. J. Med. Chem. 1993, 36, 95-100. [CrossRef]

(C) 2020 by the author. Licensee MDPI, Basel, Switzerland. This article is an open access article distributed under the terms and conditions of the Creative Commons Attribution (CC BY) license (http://creativecommons.org/licenses/by/4.0/). 